\title{
Original paper \\ Petrogenetic evolution of a Late Jurassic calc-alkaline plutonic complex, Klamath Mountains Province, U.S.A.: quantification by major- and trace-element modelling
}

\author{
L. Gordon MEDARIS, Jr. ${ }^{* *}$, Martin SVOJTKA², Lukáš ACKERMAN², Spencer J. COTKIN³ \\ ${ }^{1}$ Department of Geoscience, University of Wisconsin-Madison, 1245 West Dayton, Madison, WI 53706, USA; medaris@geology.wisc.edu \\ ${ }^{2}$ Institute of Geology of the Czech Academy of Sciences, Rozvojová 269, 16500 Prague 6, Czech Republic \\ ${ }^{3} 6382$ Tahoe Rd., Woodbury, MN 55125, USA \\ * Corresponding author
}

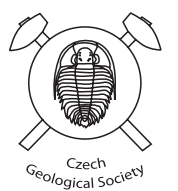

This investigation illustrates the use of major and trace elements to evaluate the petrogenetic evolution of the Late Jurassic Russian Peak Plutonic Complex in the Klamath Mountains Province, northern California, U.S.A. The two principal plutons in the complex consist of quartz diorite and granodiorite, both of which were most likely derived by partial melting of amphibolitic oceanic crustal sources and ultimately emplaced at a shallow level of $\sim 10 \mathrm{~km}\left(\mathrm{P}_{\text {total }}\right.$ $\sim 3 \mathrm{kbar}$ ). The major-element compositional variations in quartz diorite are consistent with crystallization of plagioclase $(45 \%)$ and amphibole $(69 \%)$ and resorption of clinopyroxene $(-14 \%)$. Major-element variations in granodiorite could have resulted from crystallization of plagioclase (60\%), amphibole (26\%), and biotite (14\%). Trace elements in whole-rocks and amphibole record different degrees of fractional crystallization, whole-rocks reflecting differentiation on a plutonic scale, and amphibole crystals reflecting differentiation on the scale of an individual sample. Quartz diorite experienced $10 \%$ fractional crystallization for the suite as a whole and $45 \%$ for individual samples; in contrast, granodiorite experienced $40 \%$ crystallization for the suite and $80 \%$ for individual samples. For both quartz diorite and granodiorite, comparisons of whole-rock REE patterns with those for melts calculated to be in equilibrium with amphibole demonstrate that the whole-rock REE compositions represent a combination of crystals and melts from evolving magmas, rather than melts alone.

Keywords: petrogenesis, major and trace elements, geochemical modelling, calc-alkaline plutonic complex, Klamath Mountains Province Received: 24 April 2019; accepted: 13 July 2019; handling editor: V. Janoušek

The online version of this article (doi: 10.3190/jgeosci.285) contains supplementary electronic material.

\section{Introduction}

Late Jurassic igneous complexes (154-164 Ma) are a prominent and important geological feature of the Klamath Mountains Province in northwestern California and southwestern Oregon (Barnes et al. 1992; Allen and Barnes 2006). These complexes are lithologically diverse, containing individual plutons that range in composition from gabbro to monzogranite, many of which themselves are internally zoned. Such diversity originated from a sequence of petrogenetic processes operating over the entire thickness of the crust, including derivation of magmas from the mantle, differentiation near the Moho, episodic recharge, storage and crystallization in mid-crustal magma chambers (15-20 $\mathrm{km}$ ), and final emplacement and crystallization in the upper crust (5-10 km) (Coint et al. 2013; Barnes et al. 2016; Ernst et al. 2016).

An example of this Late Jurassic magmatic activity is provided by the Russian Peak Plutonic Complex in the central Klamath Mountains (Fig. 1), in which the predom- inant plutons are quartz diorite and granodiorite, each of which exhibit a wide range in chemical composition. The mineralogy and crystallization conditions for the Russian Peak Plutonic Complex were determined previously by Cotkin and Medaris (1993); in this investigation we report major- and trace-element compositions for wholerocks and constituent minerals, by means of which petrogenetic processes influencing the geochemical evolution of the complex are quantitatively evaluated. The coeval and neighboring English Peak and Wooley Creek igneous complexes have been investigated in detail (Barnes et al. 1990, 2016; Coint et al. 2013; Ernst et al. 2016) and provide a basis of comparison for evaluating petrogenesis of the Russian Peak Complex. In contrast to the English Peak and Wooley Creek complexes, whose compositions reflect a crustal-scale petrogenetic evolution, the Russian Peak whole-rock and mineral compositions largely record the final stage of emplacement of the complex at an upper crustal level $(\sim 10 \mathrm{~km})$; the compositional ranges of quartz diorite and granodiorite are primarily the result of fractional crystallization. 


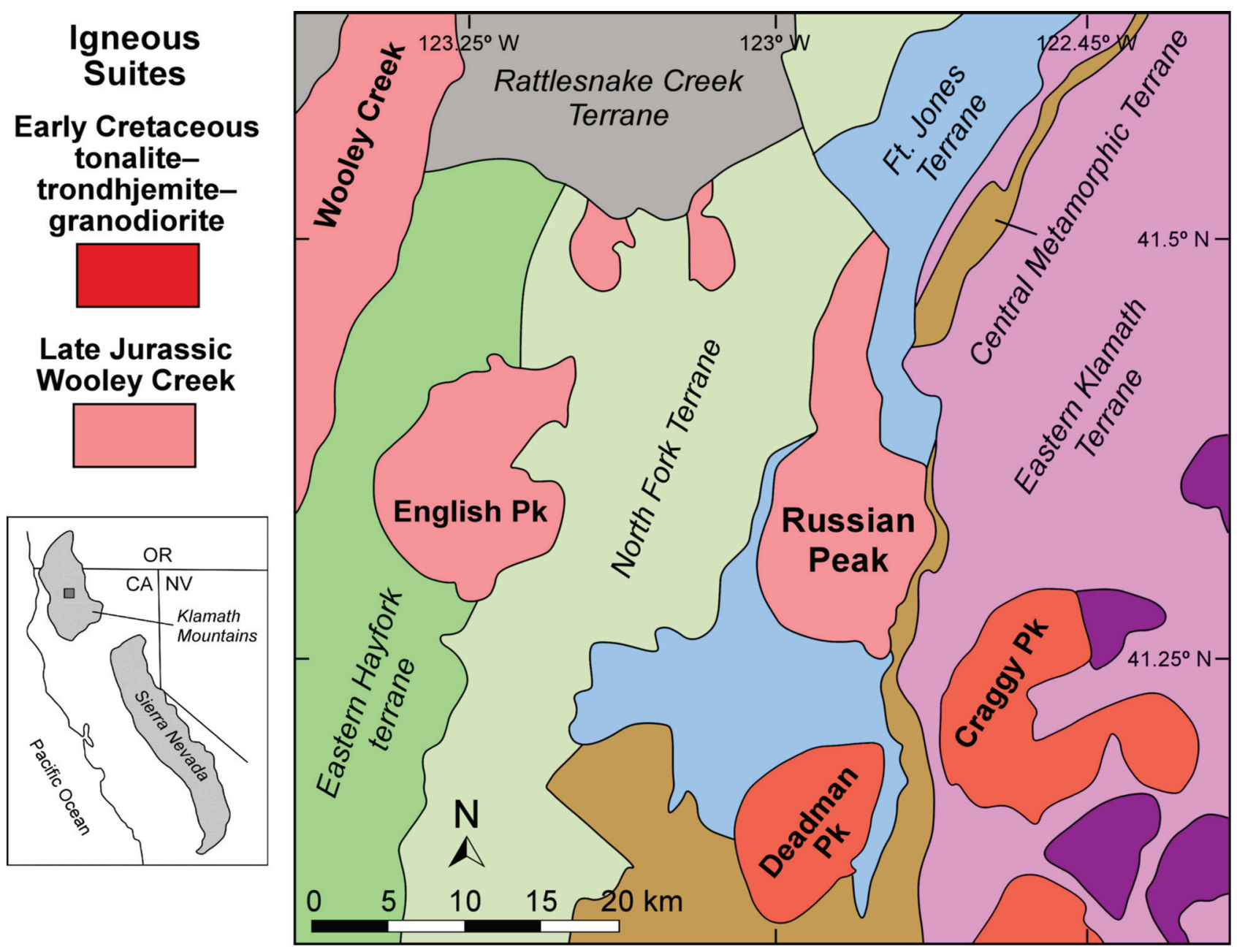

Fig. 1 Distribution of the Early Cretaceous tonalite-trondhjemite-granodiorite and Late Jurassic Wooley Creek suites of plutonic complexes and tectonostratigraphic terranes in the central Klamath Mountains Province, California and Oregon. Map modified from Allen and Barnes (2006).

\section{Geological setting}

The Klamath Mountains Province consists of a series of tectonostratigraphic terranes that were accreted progressively westward along an active continental margin (Irwin 1960, 1981; Snoke and Barnes 2006). The terranes, which generally decrease in age from Neoproterozoic to Late Jurassic from east to west, are juxtaposed along thrust faults, which also decrease westward in age. Most of the terranes contain oceanic components, including ophiolites, mid-oceanic mafic lithologies, subduction mélanges, island-arc sequences, and flysch, many of which formed in a supra-subduction setting (Harper and Wright 1984; Allen and Barnes 2006; Coint et al. 2013).

The Klamath Mountains Province was intruded by Middle Jurassic to Early Cretaceous igneous complexes that were generated during seven distinct magmatic episodes. Four of them were emplaced prior to Nevadan thrusting at 153-150 Ma, and three following thrusting. The pre-Nevadan plutons are calcic to calc-alkalic and include the arc-related Western Hayfork Terrane (178$171 \mathrm{Ma})$, Ironside Mountain Batholith (170-168 Ma), Wooley Creek suite (164-154 Ma), and Chetco Complex (160-155 Ma), whereas the post-Nevadan plutons are calcic and include the Western Klamath suite (150-143 $\mathrm{Ma}$ ), the post-Western Klamath tonalite-trondhjemitegranodiorite suite (142-136 Ma), and the post-Western Klamath granodiorite suite (139-136 Ma) (Wright and Fahan 1988; Barnes et al. 1992, 2006; Hacker et al. 1995; Donato et al. 1996; Allen and Barnes 2006).

The pre-Nevadan Wooley Creek suite is the most voluminous among the seven magmatic groups and comprises thirteen igneous complexes, including the Russian Peak Plutonic Complex, that are widely distributed in the central and northern parts of the Klamath Mountains Province. The Wooley Creek suite is lithologically diverse, with intrusive centers that range from gabbro to granite, and individual plutons in the various centers are typically zoned, with a common variation being from quartz diorite and tonalite to quartz monzodiorite and 
granodiorite (Barnes et al. 1990, 1995, 2016; Gribble et al. 1990; Cotkin and Medaris 1993; Coint et al. 2013). Investigation of the Russian Peak Complex provides an opportunity to explore further the petrological variability of the Wooley Creek suite in space and time.

The Russian Peak Plutonic Complex (159 Ma) is the southeasternmost member of the Wooley Creek suite and is accompanied by the English Peak (156 Ma) and Wooley Creek (162 Ma) plutonic complexes, which are located approximately 25 and $40 \mathrm{~km}$ to the west, respectively (Fig. 1). The two predominant plutons in the Russian Peak Complex (quartz diorite and granodiorite) are similar in whole-rock and mineral compositions to the late-stage plutons in the English Peak Plutonic Complex (Yellow Jacket and Chimney Rock units) and the Wooley Creek Batholith (upper zone), and a comparison of the geochemical characteristics of these plutons provides an insight into the late-stage, upper level petrogenesis of these members of the Late Jurassic Wooley Creek igneous suite.

The Russian Peak Complex intruded the four easternmost tectonostratigraphic terranes, viz. the Eastern Klamath, Central Metamorphic, Fort Jones (Stuart Fork), and North Fork terranes, all of which are in fault contact with each other (Fig. 1; Romey 1962; Davis et al. 1965; Cotkin and Medaris 1993; Barnes et al. 2016). The Eastern Klamath Terrane is composite, consisting of Ordovician ultramafic rocks (Trinity Complex), Silurian gabbros, Lower Devonian to Middle Jurassic marine clastic and volcaniclastic rocks, volcanic rocks, and limestone (Redding Subterrane), and Silurian to Devonian mélange and volcaniclastic turbidites (Yreka Subterrane). The Central Metamorphic Terrane consists of Devonian oceanic crust that includes metabasite of MORB affinity (Salmon hornblende schist) and metamorphosed pelagic sedimentary rocks (Grouse Ridge Formation). The Fort Jones (Stuart Fork) Terrane is a subduction complex containing semipelitic schist and metabasic rocks that experienced Late Triassic blueschist-facies metamorphism. The North Fork Terrane consists of metachert and quartzofeldspathic argillite interstatified with ocean island basalt and overlain by island-arc tholeiite.

\section{Analytical techniques}

\subsection{Whole-rock chemical analyses}

Whole-rock chemical analyses were provided by the GeoAnalytical Laboratory at Washington State University, where major-, minor-, and selected trace-element concentrations were measured by a Thermo-ARL automated X-Ray fluorescence (XRF) spectrometer, using a low $(2: 1)$ Li-tetraborate fused bead technique, with an average precision better than $\pm 5 \%$. Concentrations of 14 rare earth elements (REE) and 13 other trace elements were measured by an Agilent Model 4500 ICP-MS instrument, using a di-lithium-tetraborate flux for fusion, with a precision of $\leq 5 \%$ for the REE and $\leq 10 \%$ for the other trace elements. The accuracy of the XRF method was monitored by repeated analyses of GSP-1 granodiorite reference material (USGS) and was better than $\pm 5 \%$ with respect to certified values.

\subsection{Electron-microprobe}

Major and minor elements in amphibole were analyzed at the University of Wisconsin-Madison by wavelengthdispersion spectrometry (WDS) with a Cameca SX50 instrument. Operating conditions were: $15 \mathrm{kV}$ accelerating voltage, $20 \mathrm{nA}$ beam current (Faraday cup), and beam diameter of $1 \mu \mathrm{m}$. Natural minerals were used as standards, viz. clinopyroxene $\left(\mathrm{SiO}_{2}, \mathrm{MgO}, \mathrm{CaO}\right)$, garnet $(\mathrm{FeO})$, rutile $\left(\mathrm{TiO}_{2}\right)$, rhodonite $(\mathrm{MnO})$, jadeite $\left(\mathrm{Al}_{2} \mathrm{O}_{3}\right.$, $\mathrm{Na}_{2} \mathrm{O}$ ), and microcline $\left(\mathrm{K}_{2} \mathrm{O}\right)$. Data reduction was performed by Probe for Windows software, utilizing the $\phi(\rho z)$ matrix correction of Armstrong (1988). The method of Schumacher (1997) was used to estimate ferrous/ferric ratios and calculate the atomic compositions (apfu) in amphibole, and the classification scheme of Leake et al. (1997) was followed for amphibole nomenclature.

\subsection{LA ICP-MS}

An Element 2 high-resolution sector field mass spectrometer (ThermoFisher Scientific) coupled with a 213nm NdYAG UP-213 laser-ablation system (New Wave Research, Inc.), housed at the Institute of Geology of the Czech Academy of Sciences in Prague, was used to acquire the trace-element concentration data. Polished thin-sections were used for in-situ laser-ablation analyses. The following isotopes were measured in the low mass resolution mode $(\mathrm{m} / \Delta \mathrm{m}=300):{ }^{45} \mathrm{Sc},{ }^{85} \mathrm{Rb},{ }^{88} \mathrm{Sr},{ }^{89} \mathrm{Y},{ }^{90} \mathrm{Zr}$, ${ }^{93} \mathrm{Nb},{ }^{133} \mathrm{Cs},{ }^{138} \mathrm{Ba},{ }^{139} \mathrm{La},{ }^{140} \mathrm{Ce},{ }^{141} \mathrm{Pr},{ }^{142} \mathrm{Nd},{ }^{152} \mathrm{Sm},{ }^{153} \mathrm{Eu}$, ${ }^{157} \mathrm{Gd},{ }^{159} \mathrm{~Tb},{ }^{163} \mathrm{Dy},{ }^{165} \mathrm{Ho},{ }^{166} \mathrm{Er},{ }^{169} \mathrm{Tm},{ }^{174} \mathrm{Yb},{ }^{175} \mathrm{Lu},{ }^{180} \mathrm{Hf}$, ${ }^{181} \mathrm{Ta},{ }^{232} \mathrm{Th}$, and ${ }^{238} \mathrm{U}$. High-purity helium carrier gas was flushed at a flow rate of $0.77 \mathrm{l} / \mathrm{min}$ and mixed with $0.8 \mathrm{l} /$ $\min \mathrm{Ar}$ prior to introduction into the mass spectrometer. Both external standards and measured samples were analyzed at identical conditions: laser ablation repetition rate of $20 \mathrm{~Hz}$ and the laser fluence of $4.0 \mathrm{~J} / \mathrm{cm}^{2}$. The laser beam size was $80 \mu \mathrm{m}$ with a $100 \mu \mathrm{m}$ long line, 8 passes, and a speed of $5 \mu \mathrm{m} / \mathrm{s}$. Data for the gas blank were acquired for $35 \mathrm{~s}$ followed by $160 \mathrm{~s}$ of laser ablation signal. The washout time was $60 \mathrm{~s}$ between measurement of individual laser spots. Internal standardization with ${ }^{44} \mathrm{Ca}$ was used to correct for the matrix effect and the signal drift of 
the ICP-MS. The data were calibrated against an external standard of synthetic silicate glass NIST SRM 612, using the recommended values from Jochum et al. (2011) to calculate absolute concentrations in the analyzed grains. The time-resolved signal data were processed using the Glitter software (van Achterbergh et al. 2001). The values of minimum detection limit (MDL) for individual elements (Tab. 4) were calculated by multiplying the variance on the background count measurements (based on

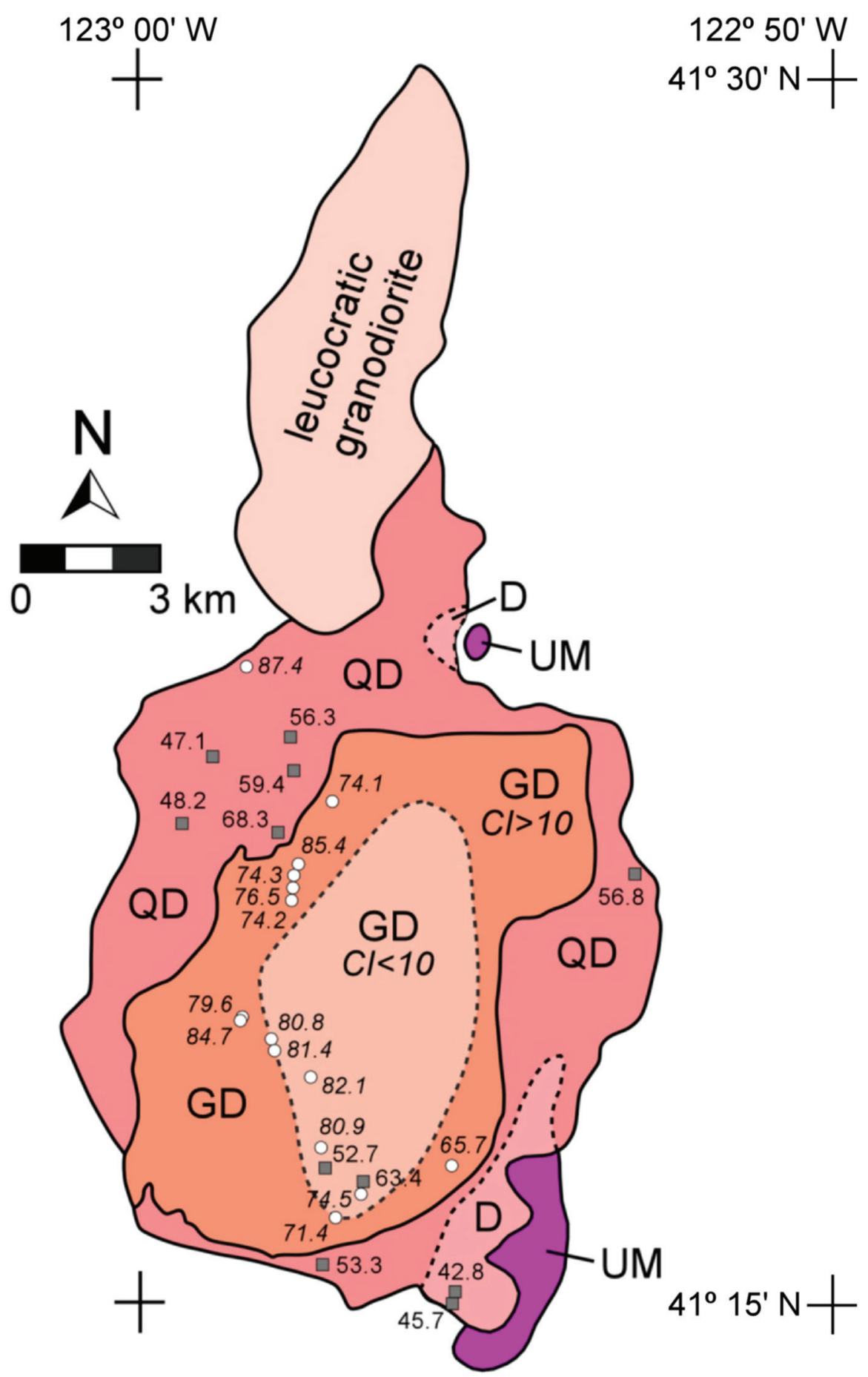

counting statistics) by 3.25 and converted to an elemental MDL using the isotopic abundance and the yield ratio between the element of interest and the internal standard element in the unknown and standard.

\section{Petrology of the Russian Peak Plutonic Complex}

\subsection{Field aspects}

The Russian Peak Plutonic Complex underlies an area of $\sim 200 \mathrm{~km}^{2}$ and consists of two nested plutons, an outer one of quartz diorite and an inner one of granodiorite, and a third, elongate pluton of extensively altered leucocratic granodiorite extending to the north (Fig. 2; Romey 1962; Cotkin and Medaris 1993). In the southeast and northeast, where the quartz diorite pluton intrudes peridotite of the Trinity ultramafic complex, cumulate ultramafic rocks occur, including dunite, wehrlite, clinopyroxenite, and hornblendite, some of which display inch-scale layering (Romey 1962; Mooring 1978). These ultramafic rocks are separated from quartz diorite by a transition zone of diorite (Fig. $2)$. In this investigation, we focus on the petrogenesis of the two predominant plutons, quartz diorite and granodiorite.

The quartz diorite and granodiorite plutons consist mostly of their namesake lithologies, although each exhibits a relatively

Fig. 2 Geological map of the Russian Peak Plutonic Complex. Abbreviations: CI, color index; D, diorite; GD, granodiorite; QD, quartz diorite; UM, cumulate ultramafic rocks. Gray squares, quartz diorite sample localities; white circles, granodiorite sample localities; numbers are values of Differentiation Index for investigated samples. Granodiorite sample 87.4 is a dike in QD, and quartz diorite samples 52.7 and 63.4 are xenoliths in GD. Map modified from Romey (1962) and Cotkin and Medaris (1993). 


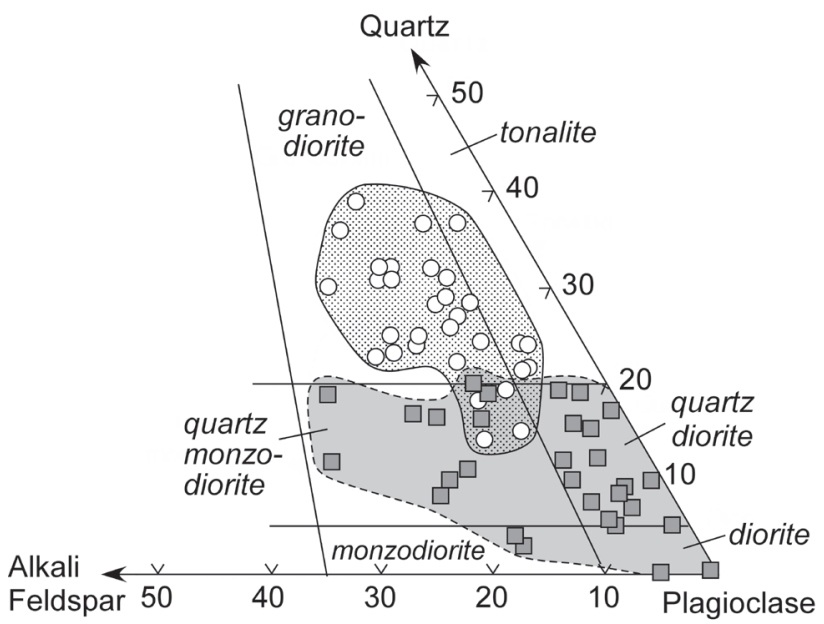

Fig. 3 Modal plot (vol. \%) of samples in the Russian Peak quartz diorite pluton (gray squares) and granodiorite pluton (white circles); nomenclature following the International Union of Geological Sciences (IUGS) classification scheme (Le Bas and Streckeisen 1991).

large variation in proportions of quartz, plagioclase, and alkali feldspar. The quartz diorite pluton consists of quartz diorite, diorite, monzodiorite, and quartz monzodiorite, whereas the granodiorite pluton consists of granodiorite, tonalite, and quartz monzodiorite (Fig. 3). These lithological variations reflect compositional zoning in the two plutons, each of which exhibits an inward increase in Differentiation Index (CIPW normative Q + $\mathrm{Ab}+\mathrm{Or}$ ) (Fig. 2). In addition, the Color Index for the granodiorite pluton is $>10$ for the outer domain and $<$ 10 for the inner domain (Fig. 2).

\subsection{Petrography}

Quartz diorite is medium-grained, equigranular to seriate, and subhedral granular; many samples exhibit a prominent igneous foliation due to the alignment of plagioclase laths and biotite flakes. Essential minerals are plagioclase $\left(\mathrm{An}_{44-25}\right), \mathrm{K}$-feldspar $\left(\mathrm{Or}_{83-89}\right)$, quartz, clinopyroxene (augite to salite), orthopyroxene (hypersthene), amphibole (magnesiohornblende) and biotite (Fig. 4; Cotkin and Medaris 1993). In quartz diorite, clinopyroxene occurs as relict grains in the cores of amphibole (Fig. 4), and in more dioritic samples, clinopyroxene is accompanied by orthopyroxene $\left(\mathrm{En}_{50-60}\right)$. Plagioclase, amphibole, and biotite are subhedral, whereas quartz and K-feldspar are interstitial and anhedral.

Granodiorite is massive to weakly foliated, mediumto coarse-grained, and subhedral granular. Essential minerals are plagioclase $\left(\mathrm{An}_{33-20}\right)$, K-feldspar $\left(\mathrm{Or}_{79-91}\right)$, quartz, amphibole (magnesiohornblende), and biotite (Fig. 5; Cotkin and Medaris 1993). As in quartz diorite, plagioclase, amphibole, and biotite are subhedral, and quartz and $\mathrm{K}$-feldspar are anhedral and interstitial.
Whereas quartz diorite is relatively unaltered, granodiorite is locally altered, with plagioclase being replaced by saussurite and sericite, and biotite by chlorite and titanite.

\subsection{Crystallization conditions}

Crystallization conditions for the Russian Peak Complex were evaluated by Cotkin and Medaris (1993), who determined that, in general, the quartz diorite magma was hotter, drier, and slightly reduced relative to the granodiorite magma. The complex is surrounded by a 1 to $3 \mathrm{~km}$-wide contact aureole consisting mainly of hornblende hornfels, with pyroxene hornfels occurring within $300 \mathrm{~m}$ of the intrusive contacts. Contact metamorphic assemblages (Goodge 1989), hornblende geobarometry, and amphi-

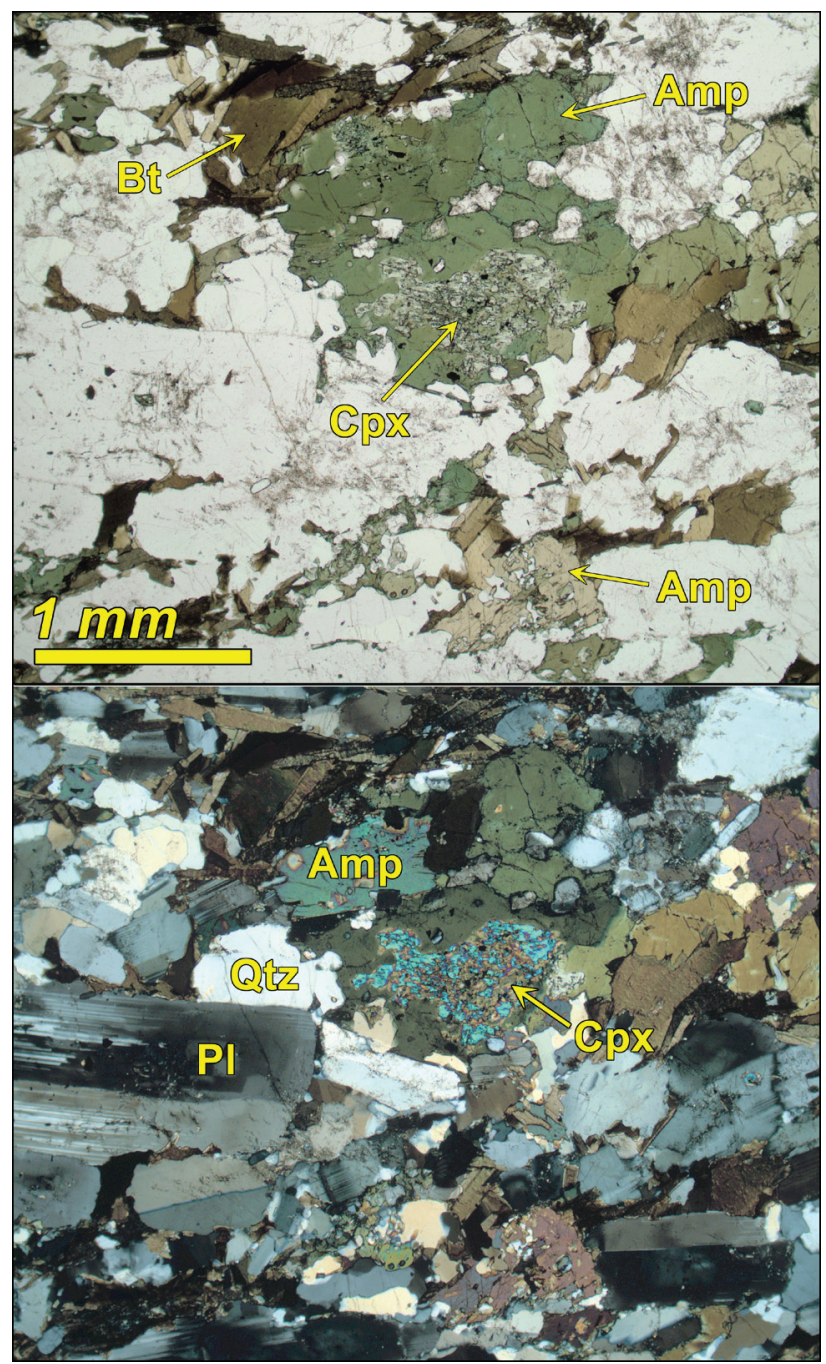

Fig. 4 Photomicrographs of Russian Peak quartz diorite sample 53.3: upper figure, plane polarized light; lower figure, crossed polarizers. Abbreviations: Amp, amphibole; Bt, biotite; Cpx, clinopyroxene; Qtz, quartz; Pl, plagioclase. 


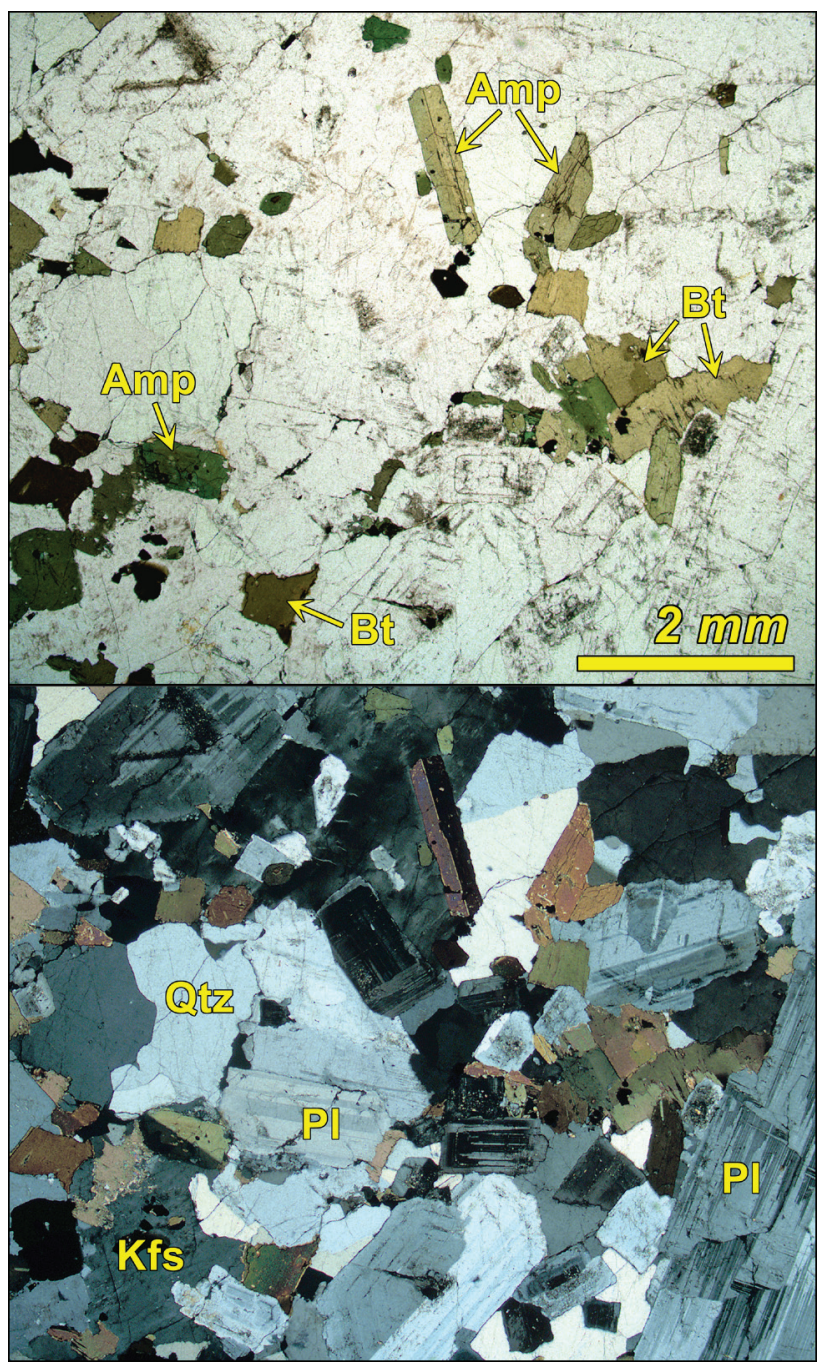

Fig. 5 Photomicrographs of Russian Peak granodiorite sample 71.4: upper figure, plane polarized light; lower figure, crossed polarizers. Abbreviations: Amp, amphibole; Bt, biotite; Kfs, potassium feldspar; Qtz, quartz; Pl, plagioclase.

bole substitution schemes indicate that the complex was emplaced at a pressure of $\sim 3 \mathrm{kbar}$.

Plagioclase and two-pyroxene geothermometry yielded crystallization temperatures of $\sim 1000^{\circ} \mathrm{C}$ for quartz diorite and $\leq 900^{\circ} \mathrm{C}$ for granodiorite (Cotkin and Medaris 1993). Amphibole geothermometry performed in this investigation, applying equation 5 in Putirka (2016) to the amphibole major-element analyses (Electronic Supplementary Material, ESM 3), yields $744-795^{\circ} \mathrm{C}$ for quartz diorite and $742-803^{\circ} \mathrm{C}$ for granodiorite, with one outlier at $825^{\circ} \mathrm{C}$. For quartz diorite, phase equilibrium analysis for the reaction phlogopite + quartz $=\mathrm{K}$-feldspar + enstatite $+\mathrm{H}_{2} \mathrm{O}$ (Cotkin and Medaris 1993), indicates that the solidus of two-pyroxene quartz diorite at a total pressure of $3 \mathrm{kbar}$ was at $\sim 780^{\circ} \mathrm{C}$ for a mole fraction of $\mathrm{H}_{2} \mathrm{O}$ of $\sim 0.55$. Comparison of the composition of granodiorite with similar ones used in crystallization experiments indicates a solidus for granodiorite of $\sim 700^{\circ} \mathrm{C}$ at $\mathrm{P}\left(\mathrm{H}_{2} \mathrm{O}\right)$ $=\mathrm{P}($ Total $)$. The absence of deuteric alteration in quartz diorite and presence of extensive deuteric alteration in granodiorite are consistent with the determination of $\mathrm{H}_{2} \mathrm{O}$-undersaturation for quartz diorite and $\mathrm{H}_{2} \mathrm{O}$-saturation for granodiorite.

Estimates of oxygen fugacity were obtained from coexisting compositions of magnetite and ilmenite in quartz diorite and magnetite, $\mathrm{K}$-feldspar, and of biotite in quartz diorite and granodiorite (Cotkin and Medaris 1993). At their respective solidus temperatures, oxygen fugacity for quartz diorite was 1.0 to $1.3 \log$ units above the quartzfayalite-magnetite (QFM) buffer, and for granodiorite was 2.1 to $2.5 \log$ units above QFM.

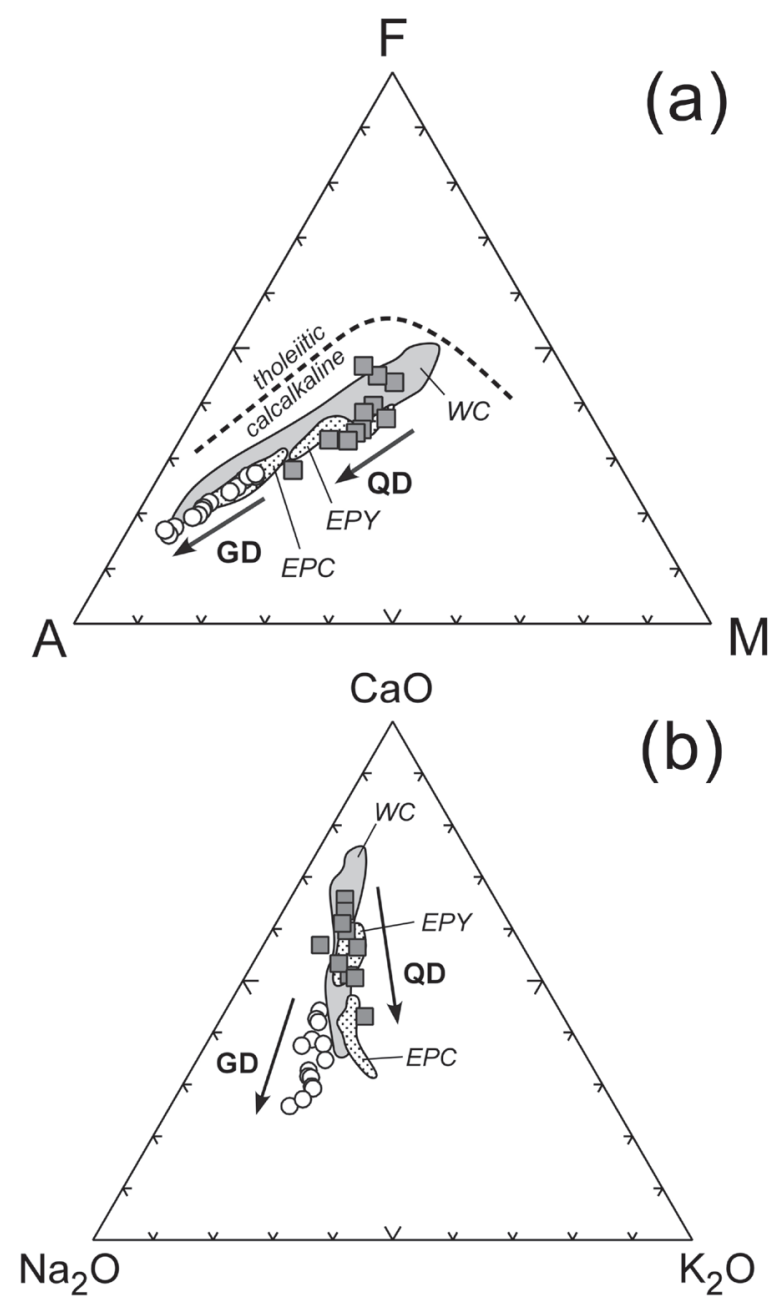

Fig. 6a $-\mathrm{AFM}\left(\mathrm{A}=\mathrm{Na}_{2} \mathrm{O}+\mathrm{K}_{2} \mathrm{O}, \mathrm{F}=\mathrm{FeO}_{\text {Total }}, \mathrm{M}=\mathrm{MgO}\right)$ plot (Barker 1983 ) for Russian Peak quartz diorite (QD, gray squares) and granodiorite (GD, white circles); arrows indicate trends of differentiation. WC, Wooley Creek upper zone; EPY, English Peak Yellow Jacket unit; EPC, English Peak Chimney Rock unit. b - Plot of molar $\mathrm{Na}_{2} \mathrm{O}-\mathrm{CaO}-\mathrm{K}_{2} \mathrm{O}$ for Russian Peak quartz diorite (QD) and granodiorite (GD); arrows indicate trends of differentiation. Other abbreviations as in panel (a). 


\section{Whole-rock chemical compositions}

\subsection{Major elements}

Major-element compositions of samples from the Russian Peak quartz diorite and granodiorite plutons (Electronic Supplementary Material, ESM 1) exhibit a pronounced calc-alkaline character in an AFM plot (Barker 1983) (Fig. 6a) and overlap with samples from the late-stage calc-alkaline Wooley Creek and English Peak plutons. In a plot of molar $\mathrm{Na}_{2} \mathrm{O}-\mathrm{CaO}-\mathrm{K}_{2} \mathrm{O}$ (Fig. $6 \mathrm{~b}$ ), samples of quartz diorite lie along the trend for the Wooley Creek and English Peak samples, but samples of granodiorite diverge, containing a higher proportion of $\mathrm{Na}_{2} \mathrm{O}$.

Although all three igneous complexes are calc-alkaline in terms of their AFM compositions, they differ with respect to their alkali-lime indices (Peacock 1931), as seen in a plot of $\mathrm{SiO}_{2}$ vs. Modified Alkali-Lime Index (MALI $=\mathrm{Na}_{2} \mathrm{O}+\mathrm{K}_{2} \mathrm{O}-\mathrm{CaO}$ wt. \%; Frost et al. 2001; Fig. 7a). Taken together, Russian Peak quartz diorite and granodiorite are calc-alkaline, having an alkali-lime index of 58.4, whereas the English Peak and Wooley Creek plutons are calcic, having alkali-lime indices of 61.6 and 62.6, respectively (Peacock 1931).

All three complexes are magnesian and generally overlap in the $\mathrm{FeO}_{\text {total }} /\left(\mathrm{FeO}_{\text {total }}+\mathrm{MgO}\right) v \mathrm{~s}$. $\mathrm{SiO}_{2}$ plot (Fig. 7b). In terms of Aluminum Saturation Index (ASI; Shand, 1943), all three complexes are metaluminous to subaluminous, with ASI values increasing with an increase in wt. $\% \mathrm{SiO}_{2}$ (Fig. 7c). The difference in mean ASI value for Russian Peak quartz diorite $(0.81 \pm 0.05)$ compared to that in Russian Peak granodiorite $(0.99 \pm 0.02)$ is reflected by the higher proportion of biotite in the latter rock type.

Russian peak quartz diorite and granodiorite contain 54.5-63.7 and 67.1-74.4 wt. \% $\mathrm{SiO}_{2}$, respectively, and thus fall into two fields in binary plots of $\mathrm{SiO}_{2} v s$. Differentiation Index, magnesium number $(\mathrm{Mg} \#=100 \times$ molar $\mathrm{MgO} /\left[\mathrm{MgO}+\mathrm{FeO}_{\text {total }}\right]$ ) and selected oxides (Fig. 8). Taken together, quartz diorite and granodiorite exhibit a relatively smooth variation in most chemical parameters, although there is significant scatter in $\mathrm{Al}_{2} \mathrm{O}_{3}$ and $\mathrm{K}_{2} \mathrm{O}$ in quartz diorite and in $\mathrm{Na}_{2} \mathrm{O}$ and $\mathrm{K}_{2} \mathrm{O}$ in granodiorite, which may be due to crystal accumulation of feldspars. Most chemical parameters in both plutons either increase or decrease with an increase in $\mathrm{SiO}_{2}$ concentration, except for $\mathrm{Mg} \#$ in quartz diorite, which increases at $\mathrm{SiO}_{2}$ concentrations below $58 \%$ and decreases at concentrations above this value.

Russian Peak quartz diorite is compositionally similar to the English Peak Yellow Jacket Pluton, except for slightly lower concentrations of $\mathrm{Al}_{2} \mathrm{O}_{3}$ and higher concentrations of $\mathrm{Na}_{2} \mathrm{O}$ and $\mathrm{K}_{2} \mathrm{O}$ (Fig. 8). Russian Peak granodiorite resembles the Chimney Rock Pluton, except for slightly higher concentrations of $\mathrm{Al}_{2} \mathrm{O}_{3}$, notably higher concentrations of $\mathrm{Na}_{2} \mathrm{O}$, and slightly lower concentrations of $\mathrm{K}_{2} \mathrm{O}$ (Fig. 8).
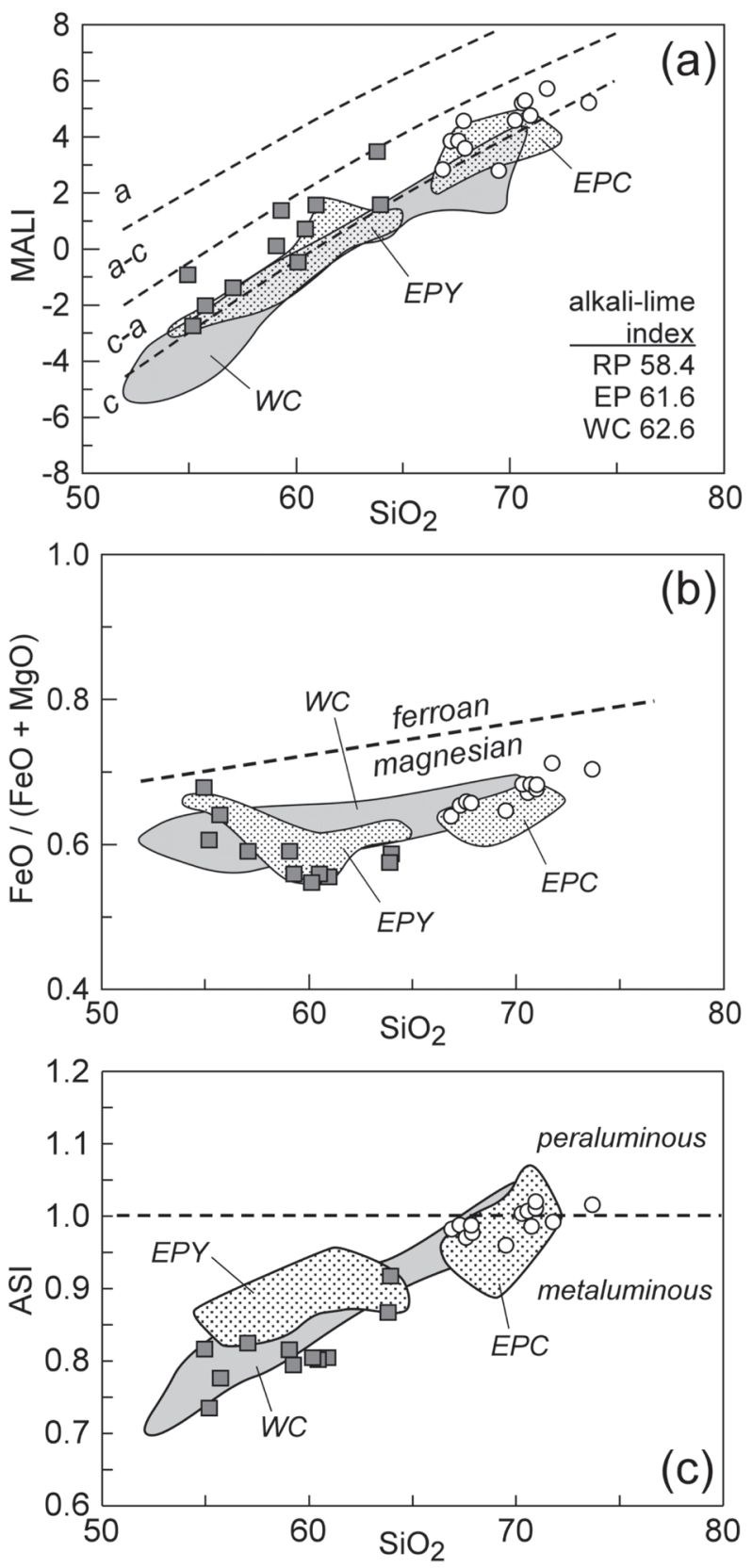

Fig. 7a - Modified alkali-lime index (MALI) vs. $\mathrm{SiO}_{2}$ (wt. \%) plot, where MALI $=$ wt. $\% \mathrm{Na}_{2} \mathrm{O}+\mathrm{K}_{2} \mathrm{O}-\mathrm{CaO}$ (Frost et al. 2001). Dashed lines indicate fields for alkalic (a), alkali-calcic (a-c), calc-alkalic (c-a), and calcic (c) rock series. Russian Peak QD, gray squares; Russian Peak GD, white circles; WC, Wooley Creek, upper zone; EPY, English Peak Yellow Jacket Pluton; EPC, English Peak Chimney Rock Pluton. Traditional alkali-lime indices for the Russian Peak (RP), English Peak (EP), and Wooley Creek (WC) suites are given in the inset. $\mathbf{b}-\mathrm{FeO} /(\mathrm{FeO}$ $+\mathrm{MgO}$ ) vs. $\mathrm{SiO}_{2}$ plot (wt. \%) showing the boundary between ferroan and magnesian granitoids (Frost et al. 2001). Symbols and labels as in panel (a). $\mathbf{c}$ - Aluminum Saturation Index (ASI) vs. $\mathrm{SiO}_{2}$ plot (wt. \%) showing the boundary between peraluminous and metaluminous rock types (Shand 1943). ASI $=$ molecular $\mathrm{Al}_{2} \mathrm{O}_{3} /\left(\mathrm{CaO}-1.67 \mathrm{P}_{2} \mathrm{O}_{5}+\mathrm{Na}_{2} \mathrm{O}+\right.$ $\mathrm{K}_{2} \mathrm{O}$ ) (Frost et al. 2001); peraluminous, $\mathrm{A}>\mathrm{CNK}$; metaluminous, $\mathrm{CNK}$ $>\mathrm{A}>$ NK. Symbols and labels as in panel (a). 

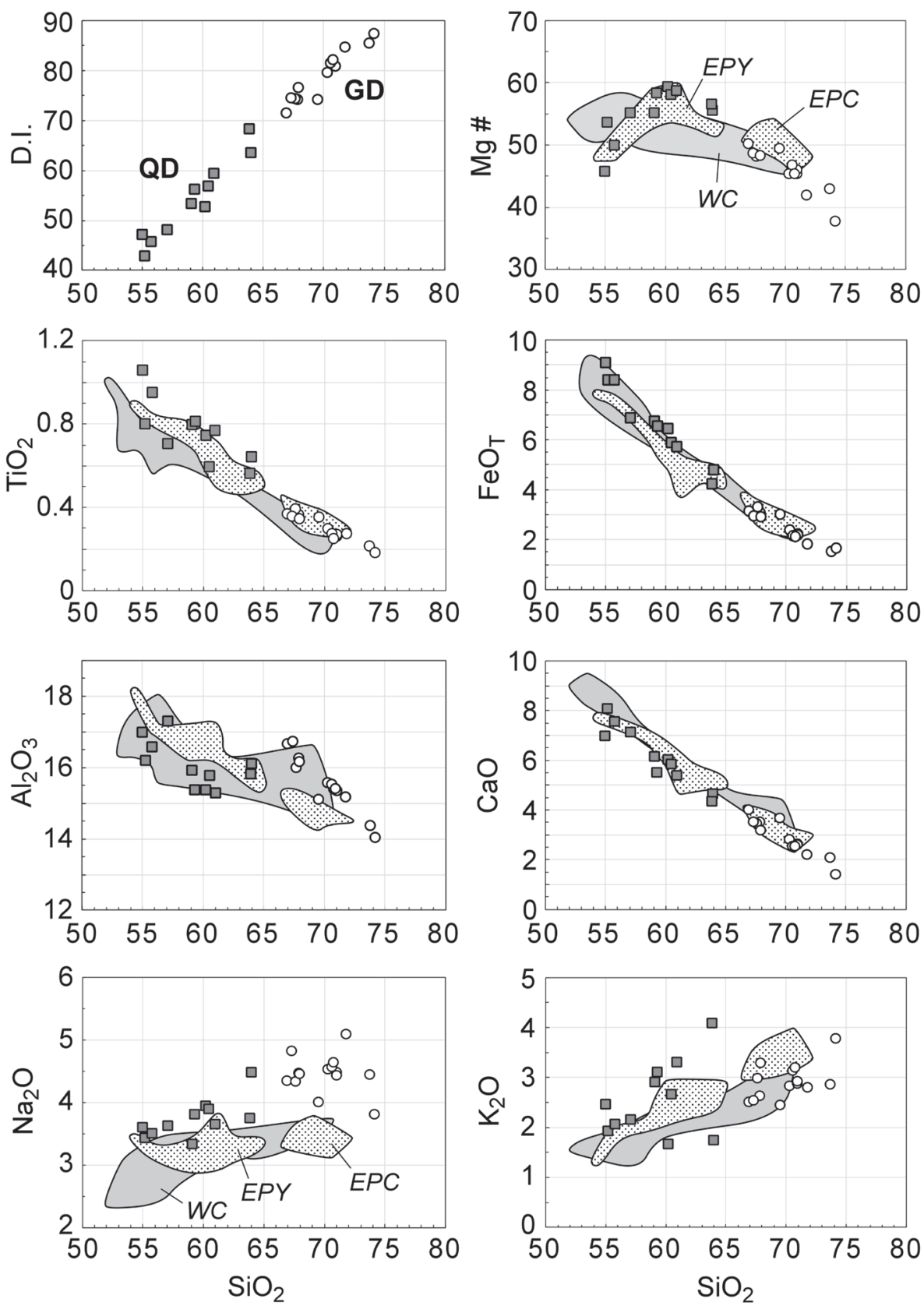

Fig. 8 Variations in Differentiation Index (D.I.), Mg-number (Mg\#), and selected major oxides (wt. \%) with respect to $\mathrm{SiO}_{2}$ (wt. \%) in Russian Peak quartz diorite (QD; gray squares) and granodiorite (GD; white circles) (a strongly altered granodiorite containing 63.4 wt. \% $\mathrm{SiO}_{2}$ is omitted from the plots). Selected parameters for the Wooley Creek and English Peak complexes are shown for comparison (Barnes et al. 1990, 2016; Coint et al. 2013). Labels: WC, Wooley Creek upper zone; EPY, English Peak Yellow Jacket Pluton; EPC, English Peak Chimney Rock Pluton.

The upper zone of the Wooley Creek Batholith is distinct from the other plutons in displaying a continuous range of $\mathrm{SiO}_{2}$ concentrations from 52 to 71 wt. \%; the compositional field for the Wooley Creek upper zone overlaps those of the other plutons, except for the higher $\mathrm{Na}_{2} \mathrm{O}$ contents in Russian Peak quartz diorite and granodiorite (Fig. 8).

\subsection{Trace elements}

Whole-rock trace-element concentrations are given in the ESM 2. In binary plots of selected trace elements $v s$. $\mathrm{SiO}_{2}, \mathrm{Sc}$ and $\mathrm{Y}$ exhibit continuous compositional trends from Russian Peak quartz diorite to granodiorite, and
$\mathrm{Rb}, \mathrm{Sr}$, and $\mathrm{Ba}$ display discontinuities between the two plutons (Fig. 9). The variation pattern for $\mathrm{Zr}$ is distinct, displaying an increase in $\mathrm{Zr}$ with increasing $\mathrm{SiO}_{2}$ in quartz diorite and a decrease in granodiorite. The traceelement compositions of the English Peak and Wooley Creek plutons largely overlap with each other and with those for Russian Peak, except that Sr concentrations for a given $\mathrm{SiO}_{2}$ content are higher in Russian Peak granodiorite, and $\mathrm{Y}$ concentrations in the English Peak Complex are higher than those in Russian Peak and Wooley Creek. The $\mathrm{Zr}$ variation pattern for Russian Peak is matched by those for English Peak and Wooley Creek, except that in the Wooley Creek Batholith the initial increase in $\mathrm{Zr}$ 
Fig. 9 Concentrations of selected trace elements (ppm) in Russian Peak quartz diorite (QD, gray squares) and granodiorite (GD, white circles). Compositions of the Wooley Creek and English Peak complexes shown for comparison (Barnes et al. 1990, 2016; Coint et al. 2013). Labels: WC, Wooley Creek upper zone; EPY, English Peak Yellow Jacket Pluton; EPC, English Peak Chimney Rock Pluton.
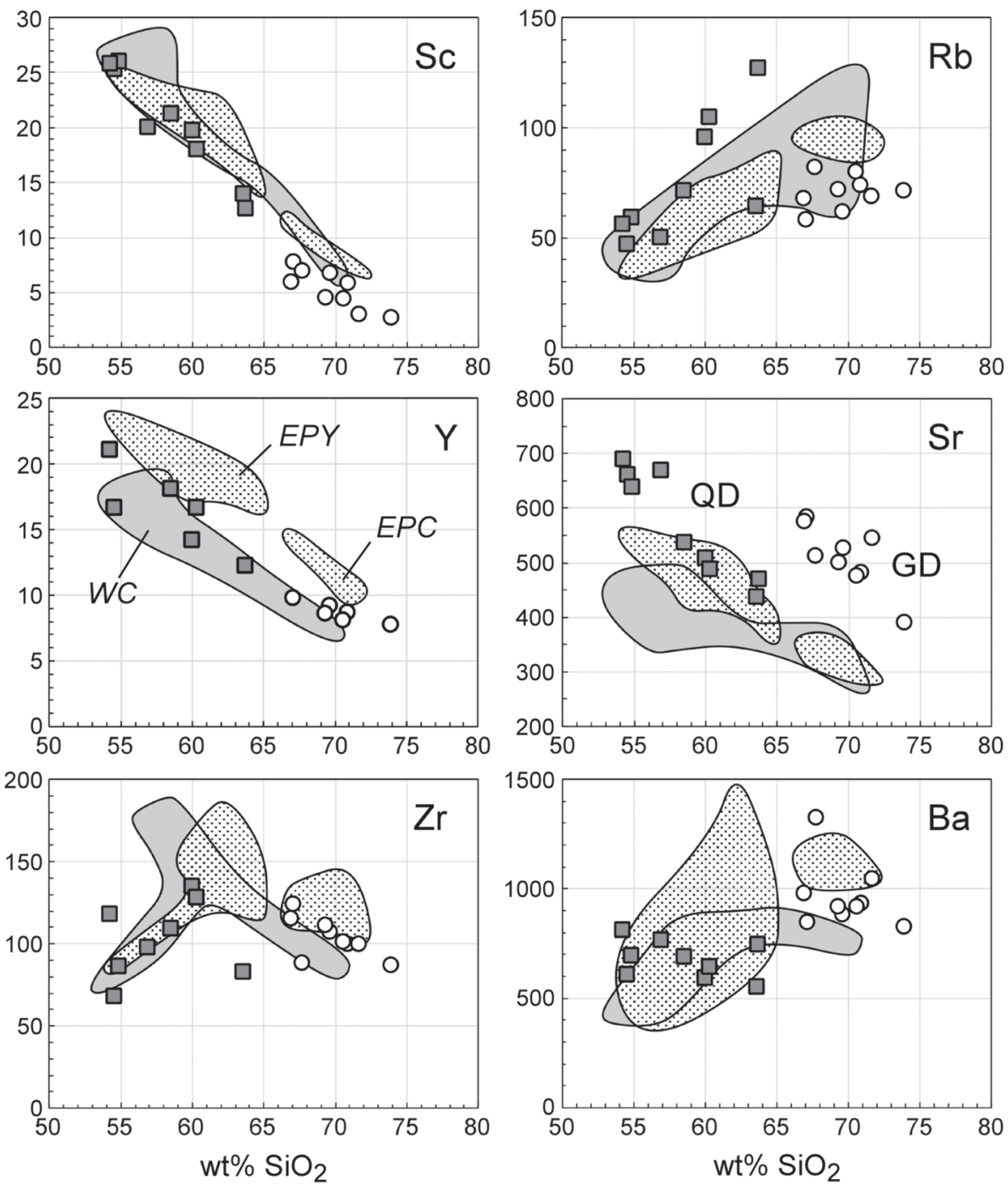

with $\mathrm{SiO}_{2}$ is followed by a decrease in $\mathrm{Zr}$ with further increase in $\mathrm{SiO}_{2}$.

The Russian Peak quartz diorite and granodiorite plutons both have a narrow range in REE concentrations; the mean values and standard deviations for $\mathrm{La}$ and $\mathrm{Yb}$, normalized to chondrite (McDonough and Sun 1995), are $77 \pm 14$ and $9.1 \pm 1.6$ in quartz diorite $(n=6)$ and $69 \pm 22$ and $5.0 \pm 0.4$ in granodiorite $(\mathrm{n}=6)(\mathrm{Fig} .10)$. The $(\mathrm{La} / \mathrm{Yb})_{\mathrm{N}}$ ratio in granodiorite, $13.8 \pm 4.3$, is slightly greater than that in quartz diorite, $8.5 \pm 3.5$. Neither suite exhibits a significant $\mathrm{Eu}$ anomaly; $\mathrm{Eu} / \mathrm{Eu}^{*}$ in quartz diorite is $0.94 \pm 0.08$ and in granodiorite is $1.06 \pm 0.05$. The light rare-earth element (LREE) concentrations for the English Peak and Wooley Creek plutons are similar to those for the Russian Peak quartz diorite and granodiorite, and their heavy rare-earth element (HREE) concentrations are about the same as those in Russian Peak quartz diorite but are about two times greater than those in Russian Peak granodiorite (Fig. 10).

In chondrite-normalized extended trace-element plots (Fig. 11), Russian Peak quartz diorite and granodiorite both display negative anomalies for $\mathrm{Nb}, \mathrm{Ta}, \mathrm{Pb}$ and $\mathrm{Ti}$, and positive anomalies for Th, U and Sr. Quartz diorite and granodiorite differ with respect to $\mathrm{Zr}$ and $\mathrm{Hf}$, the former having slightly negative anomalies and the latter, positive anomalies. The English Peak Yellow Jacket and Chimney Rock plutons have extended trace-element patterns similar to that for Russian Peak, except for subdued $\mathrm{Zr}$ and $\mathrm{Hf}$ anomalies and the absence of a $\mathrm{Sr}$ anomaly (Fig. 11). The upper zone of the Wooley Creek Complex (not figured) also has a trace-element pattern like that of Russian Peak, including both small negative and small positive anomalies for $\mathrm{Zr}$ and $\mathrm{Hf}$.

\section{Amphibole compositions}

\subsection{Major elements}

Amphibole analyses from both Russian Peak quartz diorite and granodiorite (ESM 3) correspond to magne- 

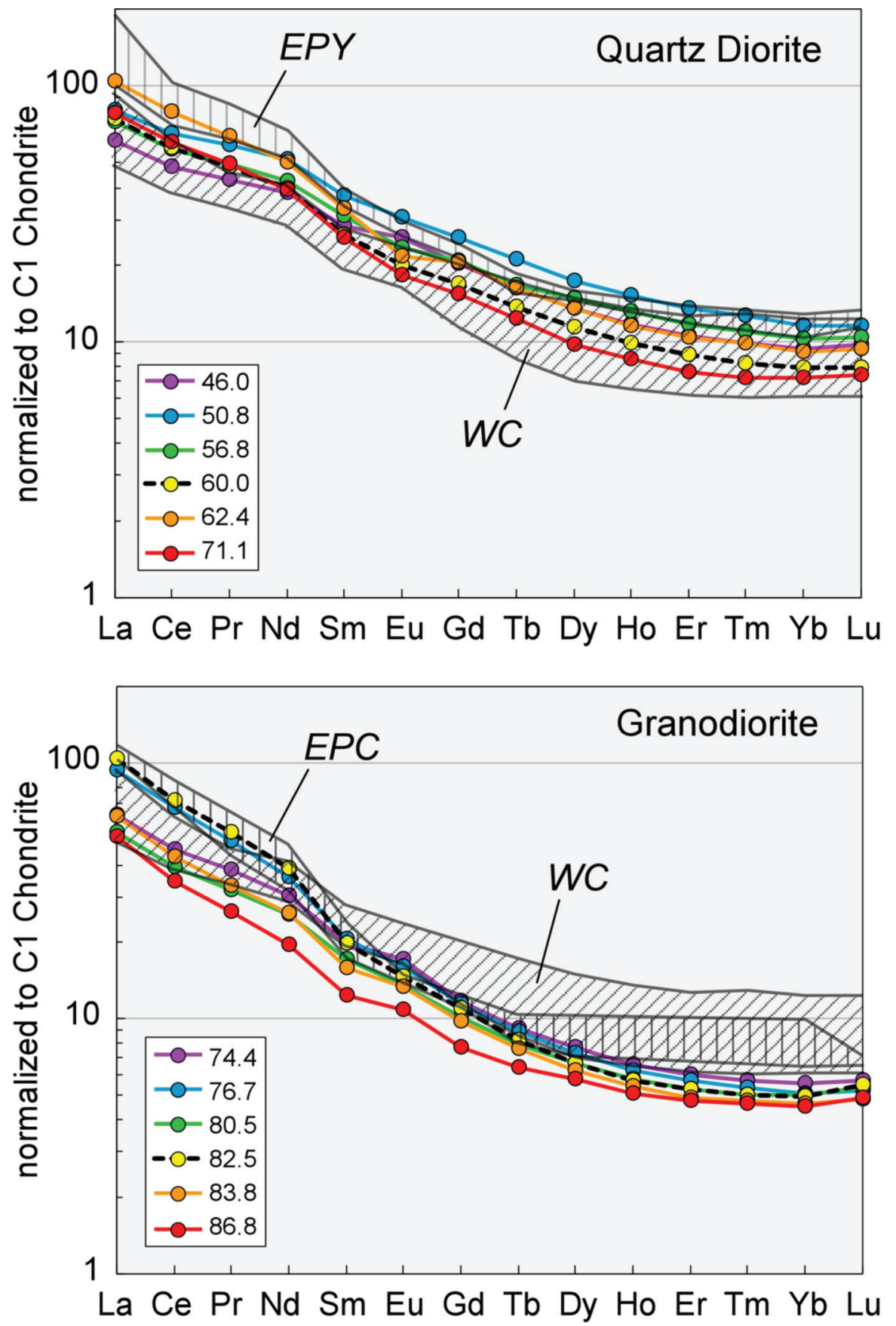

Fig. 10 Chondrite-normalized whole-rock REE compositions of Russian Peak quartz diorite and granodiorite samples, identified by values of Differentiation Index (numbers in the legend) and compared to those of the Wooley Creek upper zone (WC; diagonal stripes), English Peak Yellow Jacket Pluton (EPY; upper panel, vertical stripes) and Chimney Rock Pluton (EPC; lower panel, vertical stripes). $\mathrm{C} 1$ chondrite from McDonough and Sun (1995). siohornblende in the classification scheme of Leake et al. (1997) (Fig. 12), although slight elemental differences occur between the two plutons. When the composition of amphibole in quartz diorite is compared in detail to that in granodiorite, mean $\mathrm{Si}$ contents per formula unit are slightly higher $(6.92 \pm 0.09 v s .6 .83 \pm 0.09), \mathrm{Na}$ is lower $(0.30 \pm 0.04$ vs. $0.38 \pm 0.04)$, Ti is lower $(0.10 \pm 0.01 v s$. $0.13 \pm 0.03)$, and $\mathrm{Mn}$ is lower $(0.04 \pm 0.01$ vs. $0.07 \pm 0.01)$.

The compositions of Russian Peak amphibole lie largely within the compositional fields for cores of amphibole in the English Peak Yellow Jacket and Chimney Rock plutons, except for Ti, which is lower (for a given
Si content) at Russian Peak compared to that for English Peak (Fig. 12). The principal difference in amphibole compositions of the two complexes is that amphibole at English Peak displays a wider range in composition than that at Russian Peak, extending from tschermakite to actinolite. This variability in English Peak amphibole is commonly exhibited by pronounced zoning in crystals, in which brown, Ti-rich cores are surrounded by green, Ti-poor rims. Such crystal zoning is largely absent or minimal in the two Russian Peak plutons, where individual amphibole grains typically exhibit relatively uniform colors in thin section (Figs 4 and 5), reflecting 
Fig. 11 Extended trace-element plots for Russian Peak quartz diorite and granodiorite whole-rock samples, identified by values of Differentiation Index (numbers in the legend) and compared to those of the English Peak Yellow Jacket (EPY; upper panel) and Chimney Rock (EPC; lower panel) plutons (stippled fields). Normalized by $\mathrm{C} 1$ chondrite of McDonough and Sun (1995).
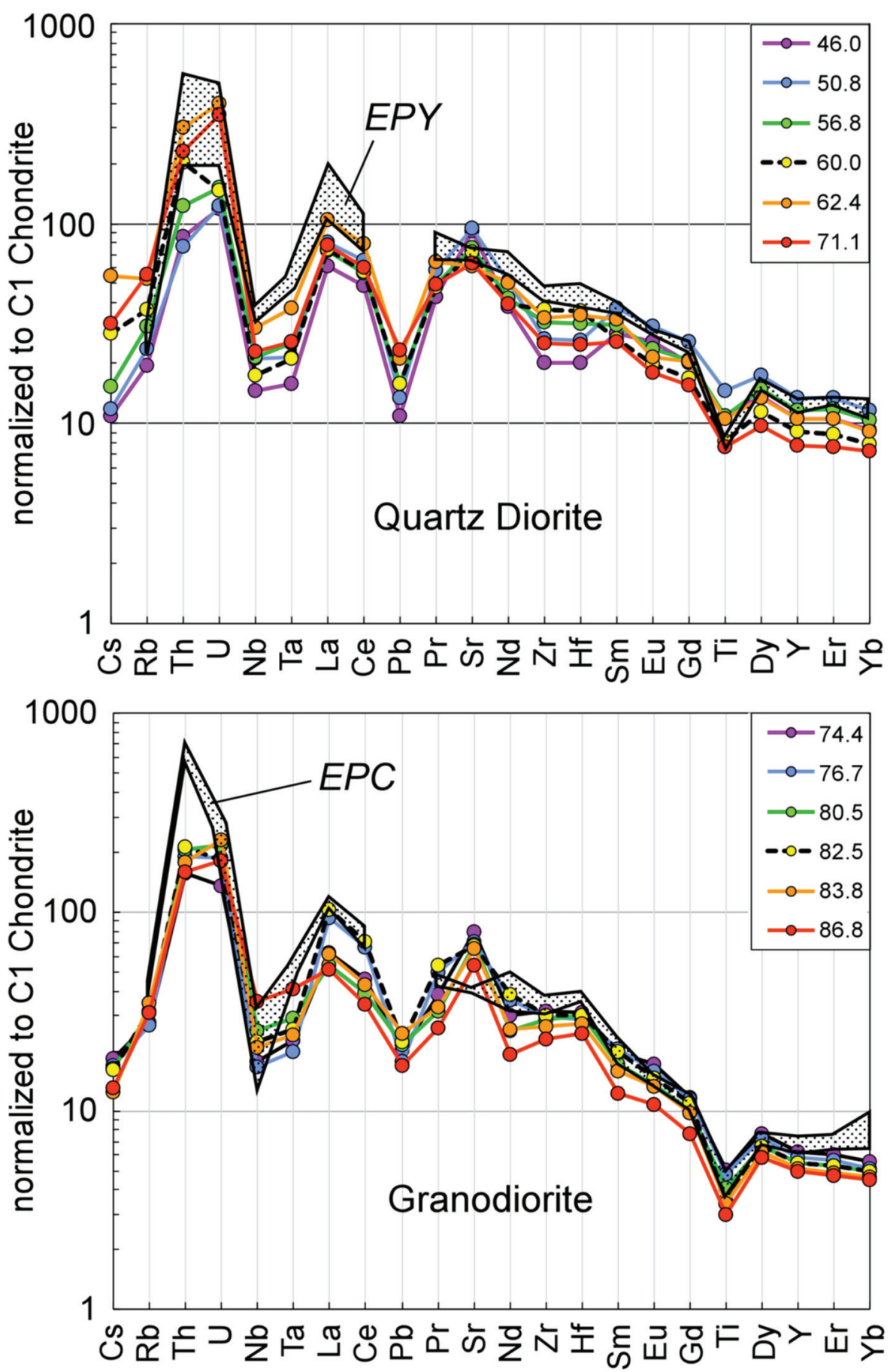

a restricted range in $\mathrm{Ti}$ contents, in contrast to those at English Peak (Fig. 12).

\subsection{Trace elements}

Trace-element concentrations in amphibole are given in the ESM 4. In Russian Peak quartz diorite, the concentrations of $\mathrm{Ba}$ in amphibole decrease continuously with a decrease in $\mathrm{Sr}$, except for two outliers that plot off-trend at Sr concentrations of 49 and $52 \mathrm{ppm}$
(Fig. 13). In contrast, plots of other trace elements $v s$. Sr exhibit a considerable degree of scatter, although there is a tendency for $\mathrm{Rb}$ to increase and Sc, $\mathrm{Y}$, and $\mathrm{Zr}$ to decrease with a decrease in $\mathrm{Sr}$, except for the two aforementioned outliers. In Russian Peak granodiorite the trace-element concentrations in amphibole exhibit an even greater degree of scatter than that in quartz diorite. Although there is a tendency for $\mathrm{Ba}$ and $\mathrm{Zr}$ to decrease with a decrease in $\mathrm{Sr}$, variations in $\mathrm{Rb}, \mathrm{Sc}$, and $\mathrm{Y}$ are more complex, with these elements initially 

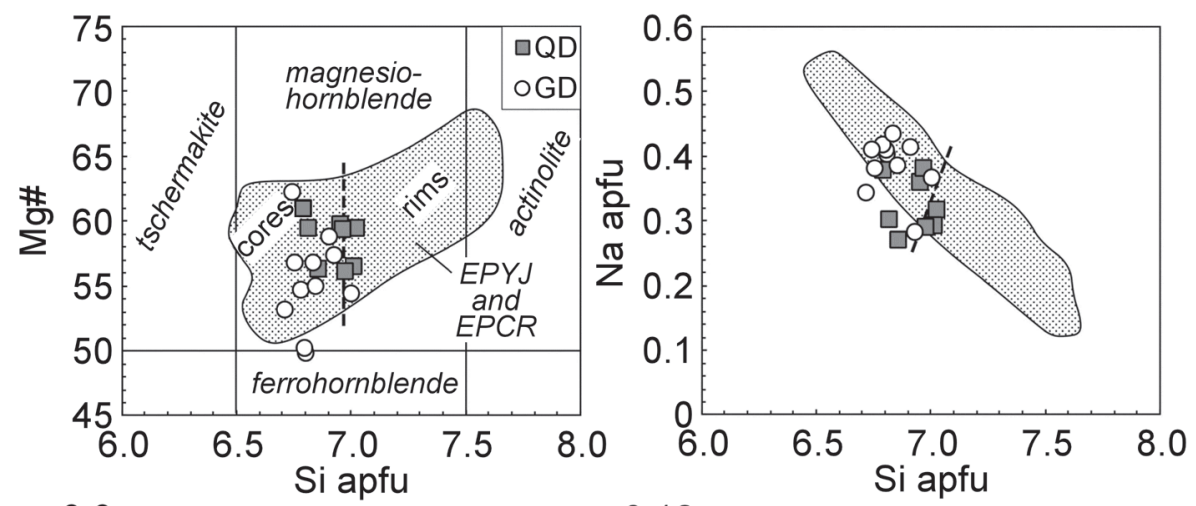
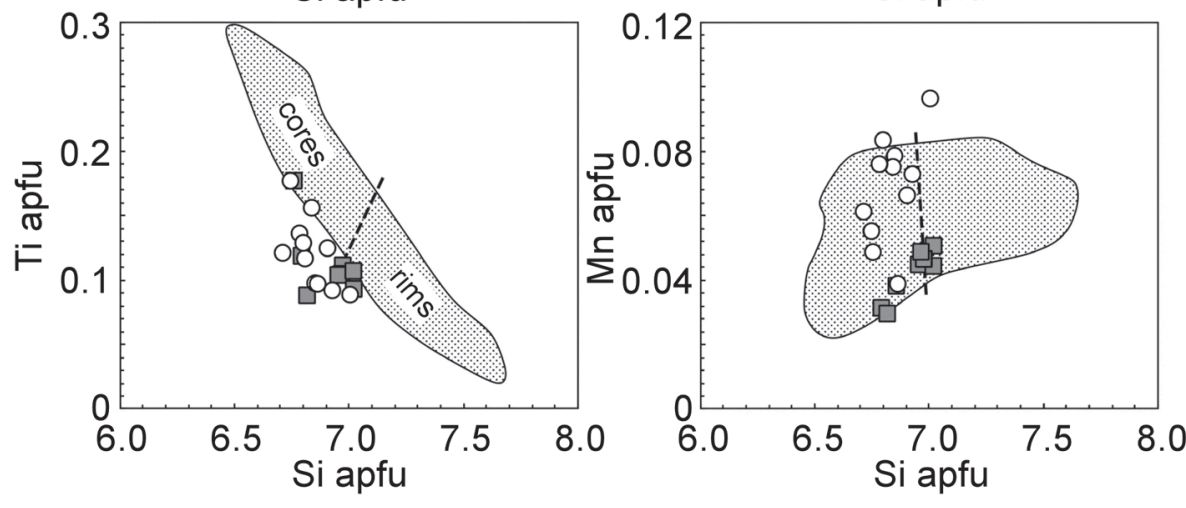

Fig. 12 Compositions of representative amphiboles in Russian Peak quartz diorite (QD; gray squares) and granodiorite (GD; white circles). Compositions of amphibole in the combined English Peak Yellow Jacket (EPYJ) and Chimney Rock (EPCR) plutons are shown for comparison (stippled fields); rims of English Peak amphibole contain higher Si concentrations than cores (Barnes et al. 2017). decreasing with a decrease in $\mathrm{Sr}$ and then increasing with a further decrease in Sr.

In general, amphibole trace-element compositions and variation patterns in Russian Peak granodiorite are similar to those in the English Peak Chimney Rock Pluton (Fig. 13). However, the concentrations of $\mathrm{Sr}$ and $\mathrm{Ba}$ in Chimney Rock amphibole extend to higher levels, $97 \mathrm{ppm}$ and 345 ppm respectively, than those in Russian Peak amphibole, which is analogous to the broader range in major-element compositions of English Peak amphibole compared to that for Russian Peak amphibole (Fig. 12). Amphibole in Russian Peak quartz diorite, however, is compositionally distinct in certain respects from that in Russian Peak granodiorite and the English Peak Chimney Rock plutons, containing much lower contents of $\mathrm{Ba}$, higher contents of $\mathrm{Y}$ at intermediate levels of $\mathrm{Sr}(20-50 \mathrm{ppm})$, and failing to show an inflection in variation pattern for Sc, Y, and Rb (Fig. 13).

Magnesiohornblende in Russian Peak quartz diorite and granodiorite exhibits a REE pattern with a convex upward shape that is characteristic of amphibole, combined with a marked negative Eu anomaly (Fig. 14). Concentrations of most of the REE in hornblende overlap in quartz diorite and granodiorite, e.g., mean values of $\mathrm{Yb}_{\mathrm{N}}$ are $52.4 \pm 25.7$ and $52.8 \pm 47.1$, respectively, and values of $\mathrm{Eu} / \mathrm{Eu}^{*}$ are $0.36 \pm 0.22$ and $0.41 \pm 0.13$.

Regarding the light rare-earth elements (LREE), the mean $\mathrm{La}_{\mathrm{N}} / \mathrm{Sm}_{\mathrm{N}}$ ratio in the three samples of quartz diorite is $0.85 \pm 0.33$. In contrast, granodiorite contains two hornblende populations with distinctly different slopes for the LREE, one that is like that in quartz diorite (mean $\mathrm{La}_{\mathrm{N}} / \mathrm{Sm}_{\mathrm{N}}=0.61 \pm 0.20$ ) and another (in sample GD9 with a Differentiation Index of 80.8) with a steeper slope $\left(\mathrm{La}_{\mathrm{N}} / \mathrm{Sm}_{\mathrm{N}}=0.09 \pm 0.02\right.$; Fig. 14). This latter population is the same one that contains elevated concentrations of $\mathrm{Rb}, \mathrm{Sc}$, and $\mathrm{Y}$ at $\mathrm{Sr}$ concentrations below $25 \mathrm{ppm}$, reflecting an advanced degree of fractional crystallization of the parental magma (Fig. 13). The steep slope in $\mathrm{La}_{\mathrm{N}} / \mathrm{Sm}_{\mathrm{N}}$ in this latter population of amphibole may arise from the late-stage crystallization of allanite in granodiorite (Cotkin and Medaris 1993), which strongly partitions the LREE.

There is considerable overlap in the REE concentrations in hornblende cores and rims of both Russian Peak plutons, although there is a tendency for hornblende rims to contain lower REE concentrations than hornblende cores in quartz diorite, and for hornblende rims to contain higher REE concentrations than hornblende cores in granodiorite.

\section{Geochemical modeling}

\subsection{Proportions of crystallizing phases}

The proportion of crystallizing minerals required to produce a particular whole-rock major-element differen- 

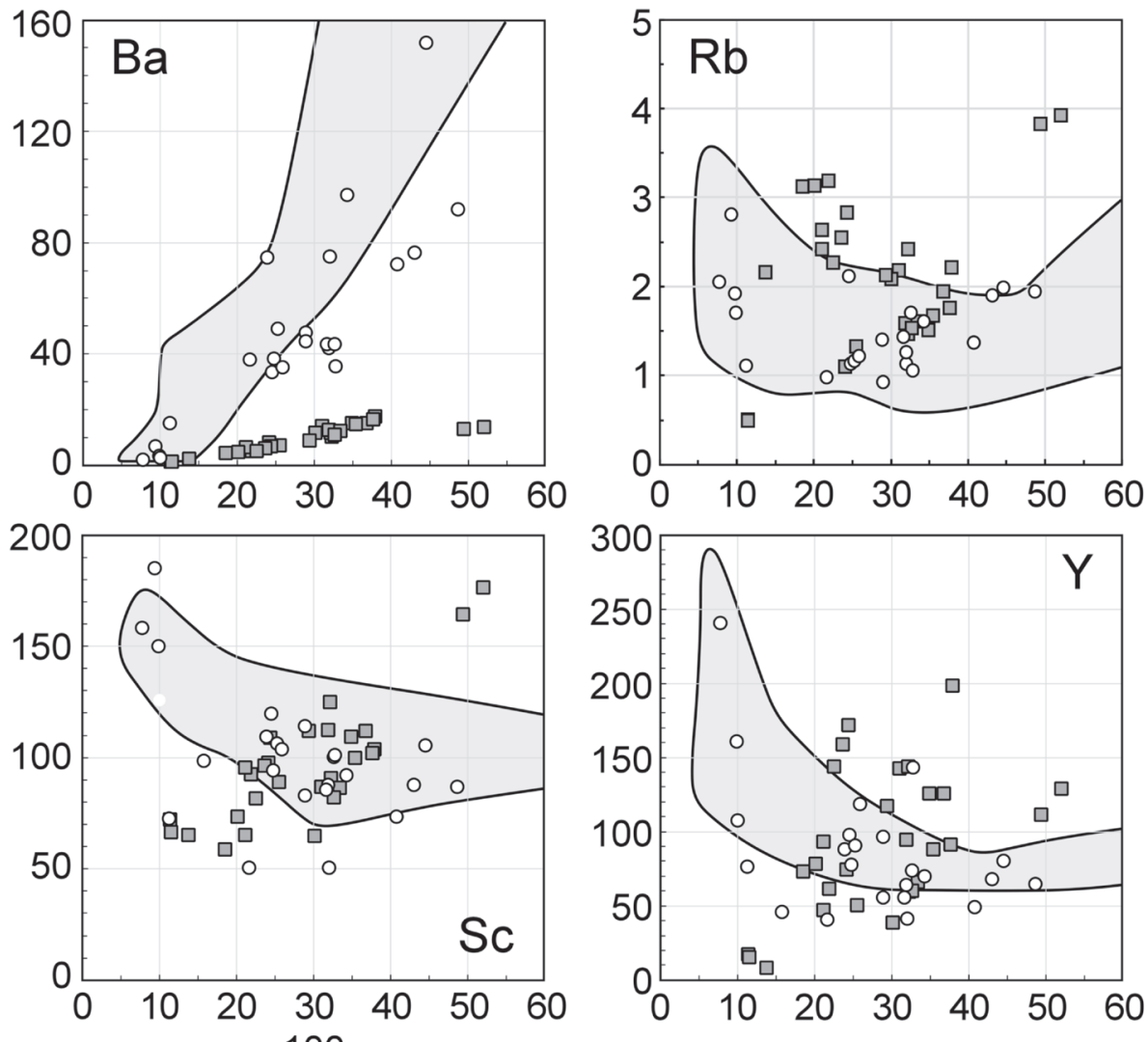

Fig. 13 Selected trace-element compositions (ppm) of amphibole in Russian Peak quartz diorite (gray squares) and granodiorite (white circles). Gray fields encompass amphibole compositions in the English Peak Chimney Rock Pluton.

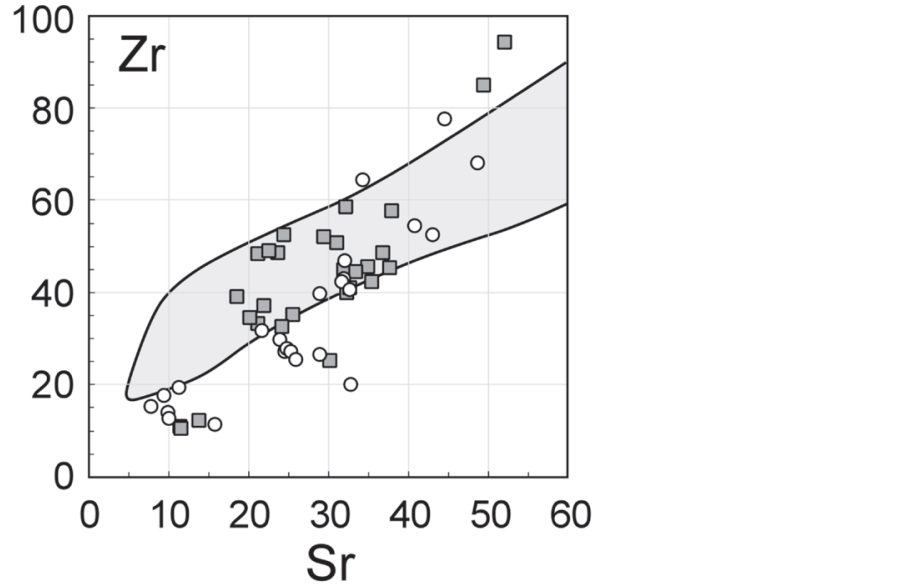

tiation trend can be determined by plotting the essential mineral and whole-rock compositions in three binary diagrams. These are then transformed and combined into an equilateral triangle, where the intersection of the three whole-rock compositional trends yields the proportion of crystallizing phases (Cox et al. 1979). This approach is illustrated in Fig. 15 for the Russian Peak granodiorite, where the small triangle of intersection yields a crystallizing proportion of $60 \%$ plagioclase, $26 \%$ amphibole, and $14 \%$ biotite. For the English Peak Chimney Rock Pluton, a slightly larger triangle of intersection is obtained, yielding a similar proportion of phases, viz. $57 \%$ plagioclase, $32 \%$ amphibole, and $11 \%$ biotite.
The same approach applied to the Russian Peak quartz diorite yields a whole-rock compositional trend that lies outside the mineral compositions in the $\mathrm{CaO}-\mathrm{SiO}_{2}$ plot and a triangle of intersection outside the mineral compositions in the transformed triangle (Fig. 16), requiring that clinopyroxene was resorbed during crystallization. The resulting proportion of phases is $69 \%$ amphibole, $45 \%$ plagioclase, and $-14 \%$ clinopyroxene (resorbed), and such resorption is consistent with the common presence of clinopyroxene cores in grains of amphibole (Fig. 4). In the English Peak Yellow Jacket Pluton, clinopyroxene was also resorbed, and the proportion of phases is $59 \%$ amphibole, $46 \%$ plagioclase, and $-5 \%$ clinopyroxene. 

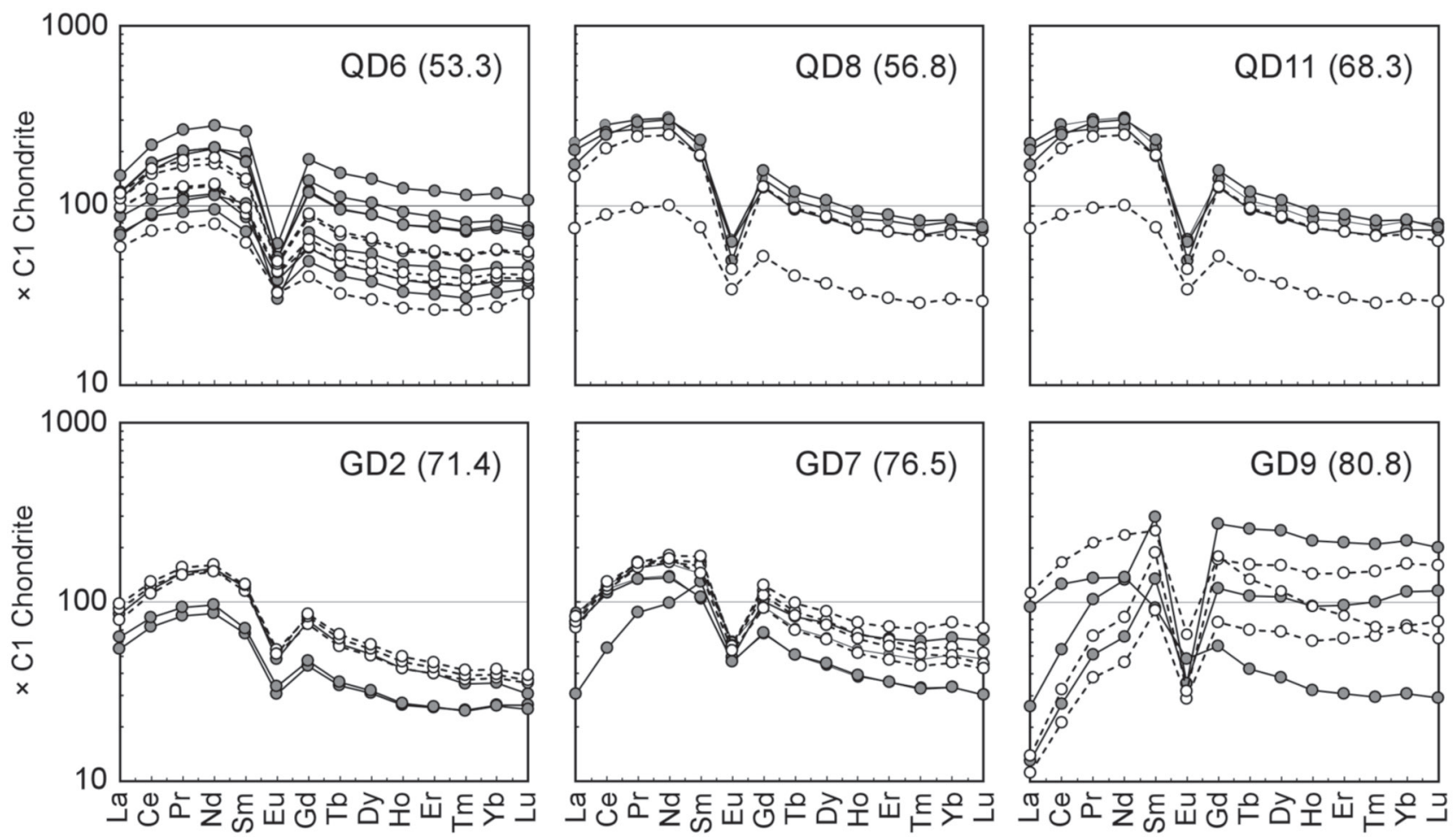

Fig. 14 Rare-earth element compositions of amphibole in Russian Peak quartz diorite (QD) and granodiorite (GD): filled circles, grain cores; open circles, grain rims. Differentiation Indices for the six figured samples are given in parentheses.

\subsection{Rare-earth element compositions of melts}

The REE compositions of melts in equilibrium with constituent amphiboles have been calculated by us-
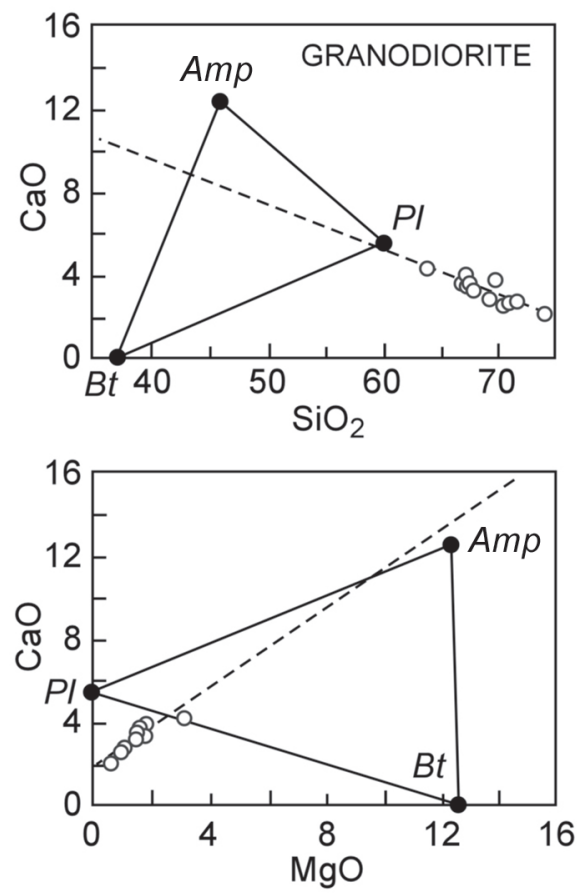

ing the partition coefficients for amphibole reported by Nandedkar et al. (2016) and Padilla and Gualda (2016); partition coefficients in the former investigation were determined experimentally at $7 \mathrm{kbar}$ and $1010-730{ }^{\circ} \mathrm{C}$ for rock types ranging from basaltic andesite $\left(51\right.$ wt. $\left.\% \mathrm{SiO}_{2}\right)$ to rhyolite (68 wt. $\% \mathrm{SiO}_{2}$ ), and those in the latter were determined by measuring the compositions of mineral rims and glass in a natural rhyolitic tuff (75.3 wt. $\left.\% \mathrm{SiO}_{2}\right)$. The $\mathrm{P}-\mathrm{T}$ conditions and chemical environment for these two sets of partition coefficients encompass those for Russian Peak quartz diorite (54.5 wt. $\%<\mathrm{SiO}_{2}<63.7$ wt. $\%$ )

Fig. 15 Russian Peak granodiorite whole-rock differentiation trends (white circles and dashed lines) and compositions of amphibole (Amp), biotite $(\mathrm{Bt})$, and plagioclase $(\mathrm{Pl})$ transformed into an equilateral triangle, from which proportions of crystallizing phases are determined (see text for explanation). Transformation of the English Peak Chimney Rock Pluton is shown for comparison. 
Fig. 16 Russian Peak quartz diorite whole-rock differentiation trends (gray squares and dashed lines) and compositions of amphibole (Amp), clinopyroxene $(\mathrm{Cpx})$, and plagioclase $(\mathrm{Pl})$ transformed into an equilateral triangle, from which proportions of crystallizing phases are determined (see text for explanation). Transformation of the English Peak Yellow Jacket Pluton is shown for comparison.
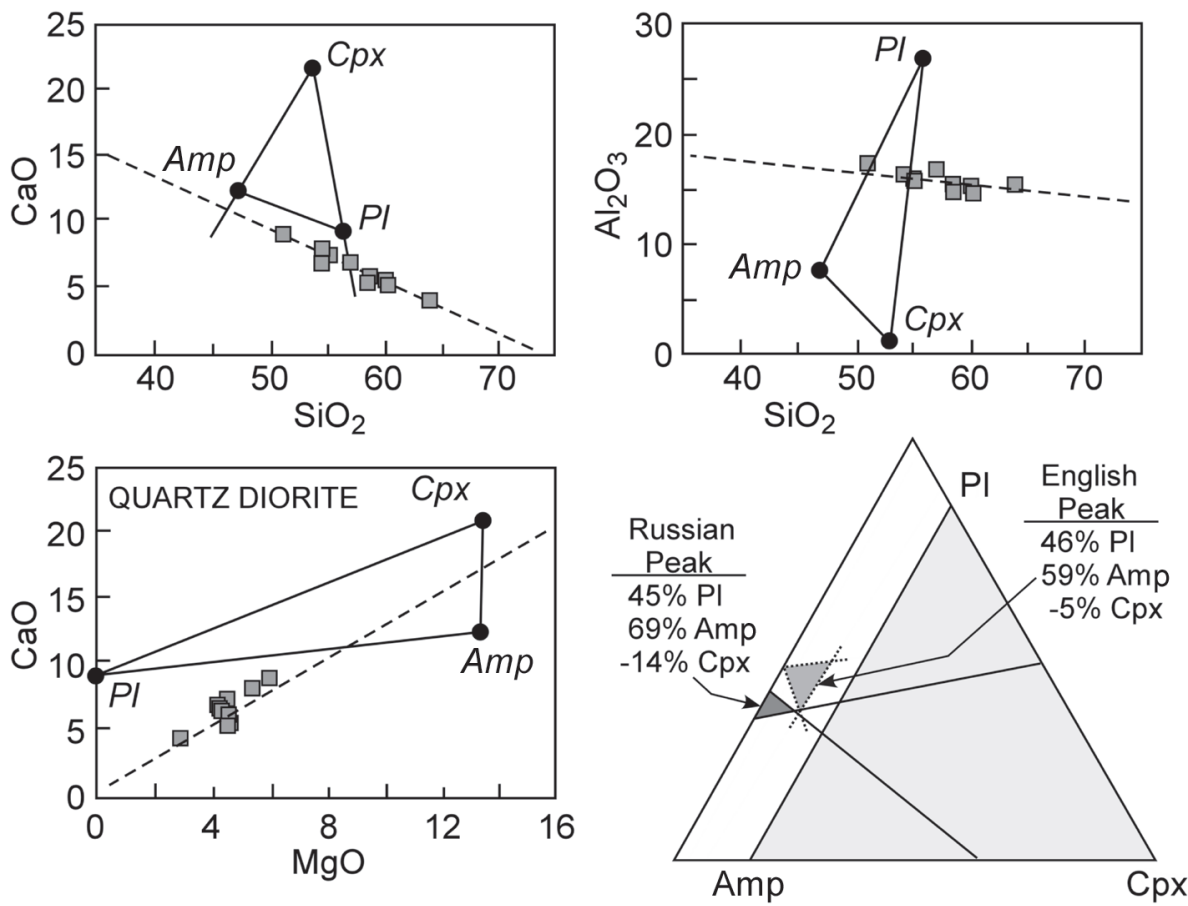

and granodiorite $\left(67.1\right.$ wt. $\%<\mathrm{SiO}_{2}<74.0$ wt. $\left.\%\right)$ and provide an appropriate basis for calculating melt compositions.
Calculated REE compositions for melt in equilibrium with amphibole in three samples of quartz diorite exhibit slightly convex downward patterns with pronounced
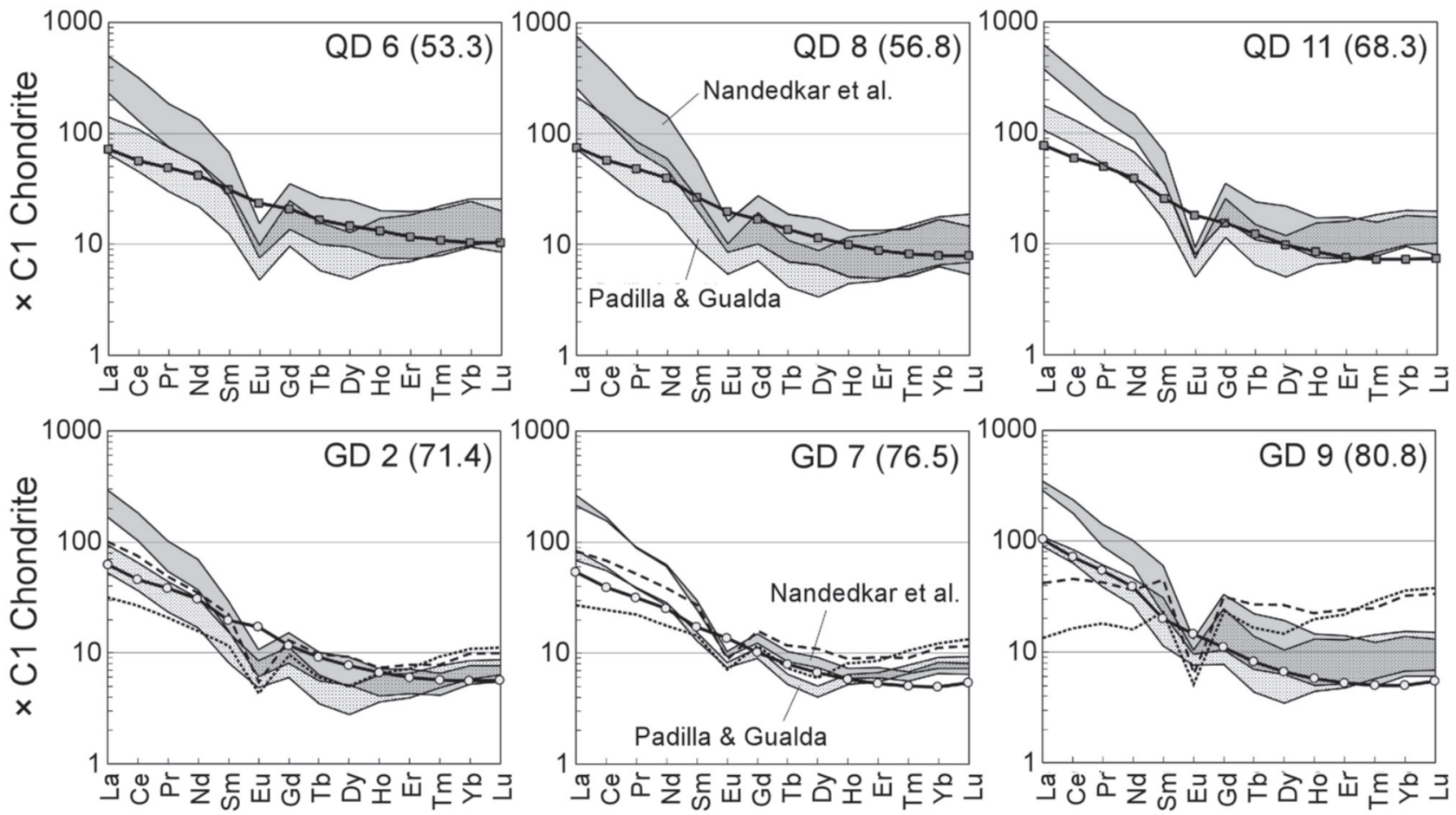

Fig. 17 Chondrite-normalized REE compositions of Russian Peak quartz diorite (samples QD6, QD8, and QD11; gray squares and solid curve) and granodiorite (samples GD2, GD7, and GD9; white circles and solid curve), with D.I. values listed in parentheses. Rare-earth element compositions of melts in equilibrium with constituent amphiboles are shown by gray fields for QD and GD and long dashes for GD, when calculated with the bulk distribution coefficients ( $D$-values) of Nandedkar et al. (2016), and by stippled fields for QD and GD and short dashes for GD, when calculated with the $D$-values of Padilla and Gualda (2016). The fields and dashed lines for granodiorite illustrate the results for the two amphibole populations in each sample. 
negative Eu anomalies (Fig. 17). The range in calculated concentrations for a given REE in each sample, especially the HREE, tends to be greater than that in the quartz diorite whole-rock suite (compare Figs 17 and 10 ), indicating greater degrees of REE fractionation on the hand sample scale compared to the plutonic scale. Granodiorite contains two populations of amphibole with respect to their REE patterns, especially in terms of $\mathrm{La} / \mathrm{Sm}$ (as described previously and illustrated in Fig. 14), thus yielding two REE patterns for calculated melts (Fig. 17). The REE pattern for melt calculated from the predominant amphibole population resembles that in quartz diorite, i.e., slightly convex downward with negative Eu anomalies, but the pattern for the subordinate
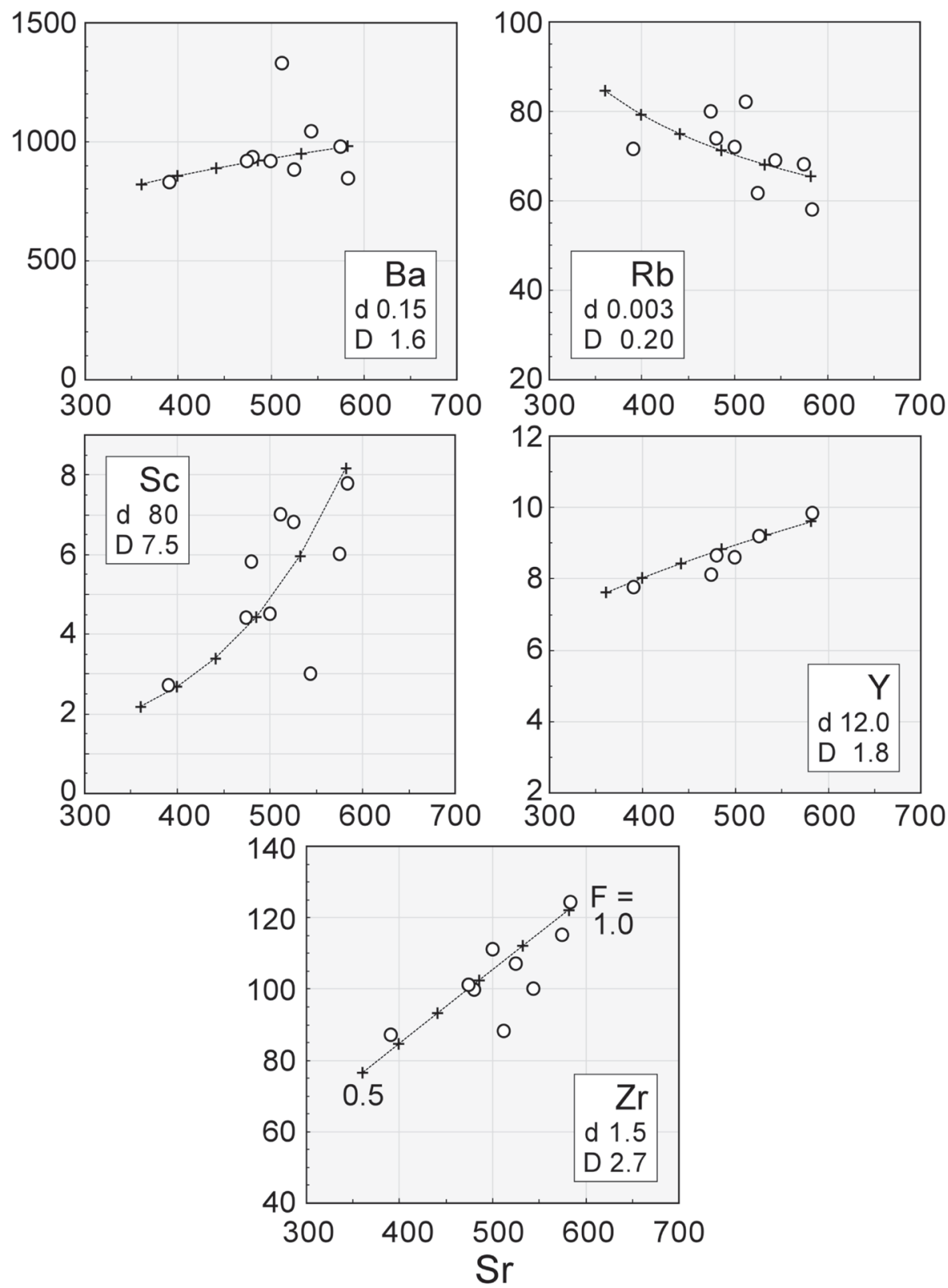

population is rotated counterclockwise, having lower LREE contents and higher HREE contents and tending to have larger negative Eu anomalies.

The whole-rock REE compositions of both quartz diorite and granodiorite compare most favorably with the melt compositions calculated from the Padilla and Gualda (2016) distribution coefficients. This suggests that distribution coefficients determined by measurements of mineral rim and glass compositions (reflecting fractional crystallization) may be more appropriate for evaluating natural rocks, such as those at Russian Peak, than experimentally determined distribution coefficients (representing equilibrium crystallization). The observed REE patterns for whole-rock quartz diorite and granodiorite samples are unlike those of the calculated melt compositions in detail, because the observed patterns represent the total REE compositions of batches of magma that consisted of an assemblage of minerals and melt at the time of emplacement.

\subsection{Whole-rock trace- element modeling}

The degree of fractional crystallization in the Russian Peak Plutonic Complex has been evaluated by the equation for classic Rayleigh fractionation (Allègre and Minster 1978):

$$
\mathrm{C}_{\mathrm{S}}=\mathrm{C}_{0} \times\left(1-\mathrm{F}^{\mathrm{D}}\right) /(1-\mathrm{F})
$$

in which $C_{S}$ is the mean concentration of the trace element of interest in the accumulated solid, $C_{0}$ is the concentration in the starting melt (which is calculated from the composition of constituent amphibole), $F$ is the fraction of melt remaining, and $D$ is the bulk distribution coefficient. Values for amphibole and

Fig. 18 Trace-element compositions (ppm) of Russian Peak granodiorite (circles) and calculated compositions of mean solids (dotted curve) for fractional crystallization from $F=1.0$ to 0.5 with nodes at 0.1 intervals (see text for explanation). Amphibole (d) and bulk (D) distribution coefficients for $\mathrm{Sr}$ are 0.23 and 2.75, respectively; values for other elements are given in the insets. 
bulk distribution coefficients were determined by trial and error to achieve the best fit between the calculated fractionation trends and the whole-rock compositions, as seen in Fig. 18 for granodiorite, where the chosen values for distribution coefficients are given in the insets (lower case $d$ for amphibole and capital $D$ for bulk). In each case the distribution coefficients for amphibole are within the ranges reported in the literature, and the bulk distribution coefficients are within a factor of 2 to 3 times the values predicted from a combination of the observed modes and calculated proportions of crystallizing phases, as explained in section 7.1.

In the suite of analyzed granodiorite samples, the concentration ranges for $\mathrm{Sr}, \mathrm{Ba}, \mathrm{Rb}, \mathrm{Y}, \mathrm{Sc}$, and $\mathrm{Zr}$ are consistent with $F \approx 0.6$, i.e., $40 \%$ fractional crystallization (Fig. 18). The $F$-values for individual samples of granodiorite, $0.98-0.60$, as determined by their positions along the calculated fractionation paths, are highly correlated $\left(\mathrm{R}^{2}=0.98\right)$ with their Differentiation Indices (CIPW normative $\mathrm{Q}+\mathrm{Ab}$ + Or), which range from 71.4 to 85.4. Two additional crystallization models (not shown in figures) were evaluated for granodiorite, one for instantaneous fractional crystallization,

$$
\mathrm{C}_{\mathrm{S}, \mathrm{i}}=\mathrm{C}_{0} \times \mathrm{D} \times \mathrm{F}^{(\mathrm{D}-1)}
$$

where $C_{S, i}$ is the concentration in the instantaneous solid, and another for equilibrium crystallization,

$$
\begin{aligned}
\mathrm{C}_{\mathrm{S}, \mathrm{e}}= & \underset{(1-\mathrm{F})]}{\left(\mathrm{C}_{0} \times \mathrm{D}\right) /[\mathrm{F}+\mathrm{D} \times}
\end{aligned}
$$

where $C_{S, e}$ is the concentration in the equilibrium solid. Models

Fig. 19 Trace-element compositions (ppm) of Russian Peak quartz diorite (square symbols) and calculated compositions of mean solids for two crystallization models: fractional crystallization (pluses and solid curve) and combined resorption and fractional crystallization for $P=0.12$ (circles and dashed curve) and $P=0.04$ (diamonds and dotted curve). Amphibole $(d)$ and bulk $(D)$ distribution coefficients are given in the insets. $F$ tick marks at intervals of 0.99 , $0.95,0.90$, and 0.80 .
(2 - instantaneous fractional crystallization) and (3equilibrium crystallization ) yield slightly higher $F$-values of 0.8 and 0.7 , respectively, than model (1). Among the three crystallization models, the aggregated fractional crystallization (1) is judged to be the most appropriate process in view of the textural and petrological characteristics of Russian Peak granodiorite.

The degree of fractional crystallization has also been calculated for quartz diorite by means of equation 1 (Fig. 19), but because clinopyroxene commonly occurs as cores in amphibole, crystallization has also been evaluated by a model involving dissolution (resorption) of clinopyroxene, as follows:
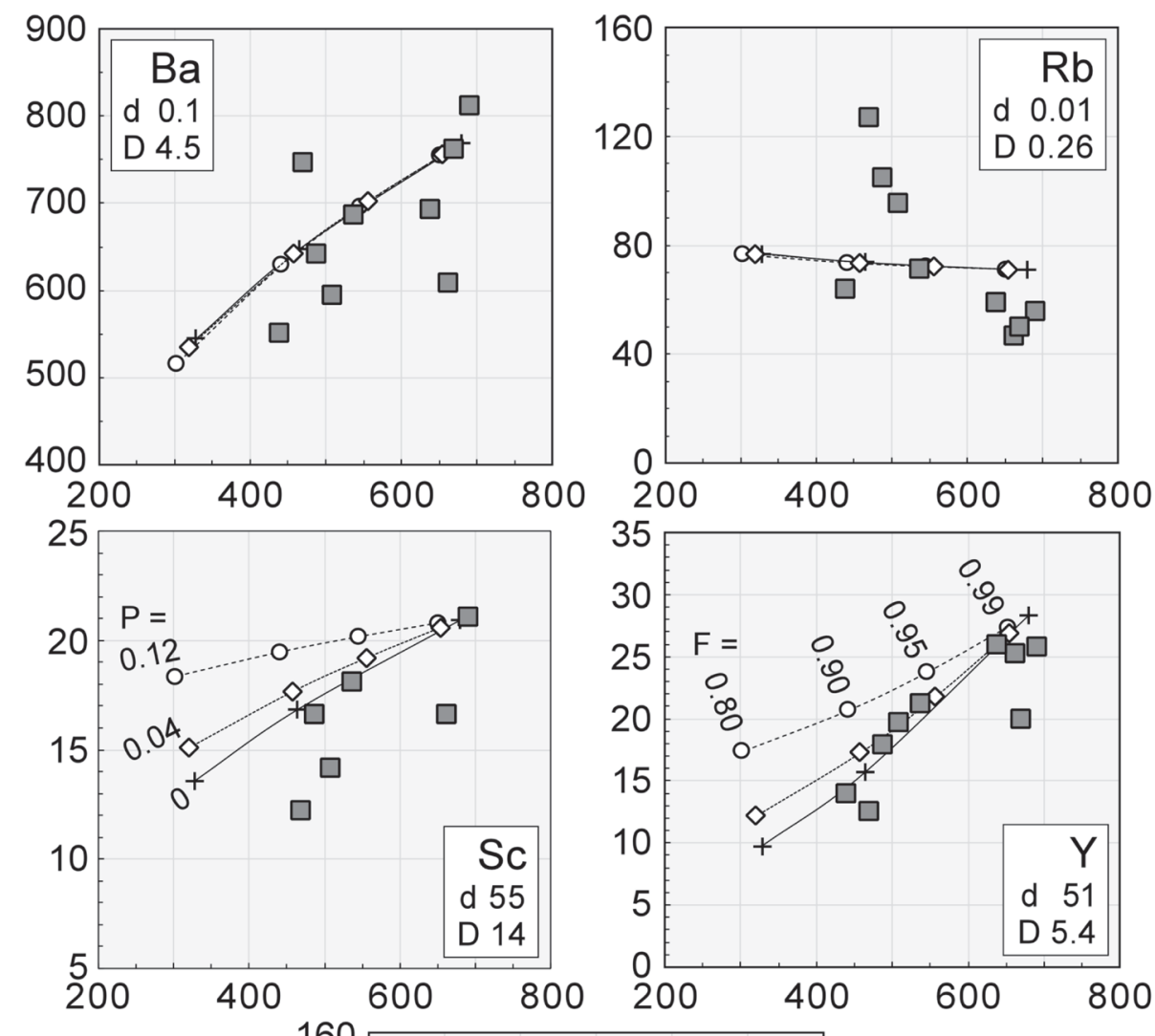

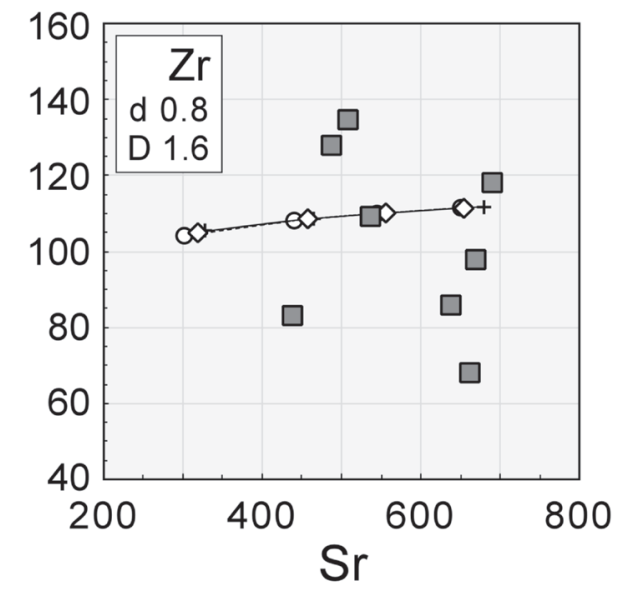




$$
\begin{aligned}
\mathrm{C}_{\mathrm{S}}= & {[1 /(1-\mathrm{F})] \times\left[\mathrm{C}_{0} \times(1-\mathrm{P})+\mathrm{C}_{\mathrm{a}} \times \mathrm{P} \times(1-\mathrm{F})-\right.} \\
& \left.\mathrm{C}_{\mathrm{L}} \times \mathrm{F} \times(1-\mathrm{P})\right]
\end{aligned}
$$

where $C_{S}$ is the mean concentration of the trace element of interest in the crystallized solid, $C_{0}$ is the concentration in the starting melt (calculated from the composition of constituent amphibole), $C_{a}$ is the concentration in the resorbed phase, clinopyroxene, $F$ is the fraction of melt remaining, $C_{L}$ is the concentration in liquid (melt) for a given $F$ (as calculated by eqn. 5.26 in Shaw 2006), and $P$ is the mass proportion of the resorbed phase, here clinopyroxene (Shaw 2006, eqn. 5.29).
As was done for granodiorite, values for amphibole and bulk distribution coefficients in quartz diorite were determined by trial and error to achieve the best fit between the calculated fractionation trends and the whole-rock compositions. In addition, the fractionation trends were chosen to pass through, or close to, the composition of sample QD6 $(\mathrm{Sr}=536 \mathrm{ppm})$, which is thought to represent the quartz diorite parent magma. Lastly, an estimate was made for the mass proportion, $P$, of resorbed clinopyroxene. For fractional crystallization alone, $10 \%$ crystallization $(F=0.9)$ is consistent with the compositional variation of the quartz diorite suite (Fig. 19). For the resorption model, a value of $\mathrm{P}=0.12$ was used initially, as determined from quartz diorite modes and major-element differentiation trends (Fig. 16). However, using such a value for $P$ generates a wide divergence between the observed and calculated compositions for $\mathrm{Sc}$ and Y (Fig. 19). Alternatively, the choice of a smaller value for $\mathrm{P}$ (e.g. 0.04) achieves a better fit between the observed and calculated compositions. This can be explained by the overgrowth of amphibole on clinopyroxene, which effectively removes early-crystallized clinopyroxene from further resorption, resulting in an accordingly smaller value of $P$ in the trace-element modelling.

The variation in $\mathrm{Rb}$ is problematic; three samples of quartz diorite, including the most differentiated one (D.I. $=68.3$ ), lie well above the calculated differentiation trends (Fig. 19), and no combination of distribution coefficients and values of $P$ achieves a successful match. These three samples also contain relatively high concentra-

Fig. 20 Trace-element compositions (ppm) of amphibole cores (filled squares) and rims (open squares) in Russian Peak quartz diorite. Dotted curves show amphibole compositions calculated for Rayleigh fractionation from $F=1.0$ to 0.4 at 0.1 intervals. The bulk distribution coefficient for $\mathrm{Sr}$ is 3.0 , and those for the other trace elements are given in the insets. 
tions of the fluid-mobile Large Ion Lithophile Elements (LILE), and their Rb and LILE compositions may reflect some degree of cryptic hydrothermal alteration.

An acceptable match is found for the observed and calculated values of $\mathrm{Zr}$, although there is considerable scatter in the $\mathrm{Zr}-\mathrm{Sr}$ variation pattern, perhaps arising from the difficulty in obtaining representative analyses for $\mathrm{Zr}$ in individual rock samples that contain small amounts of zircon that may be distributed heterogeneously. Moreover, this calculation exercise is problematic for more siliceous compositions, because granodiorite was already saturated with respect to zircon, as indicated by the negative correlation of whole-rock $\mathrm{Zr}$ concentration with $\mathrm{SiO}_{2}$ (Fig. 9) and positive correlation with $\mathrm{Sr}$ (Fig. 20). Therefore, the $\mathrm{Zr}$ budget in granodiorite was governed by zircon saturation/mass balance rather than standard Rayleigh-type fractionation.

\subsection{Amphibole trace-element modeling}

For an idealized case in which a mineral/melt partition coefficient is approximately constant over the range of $F$ (fraction of melt remaining) values and temperature of a crystallizing magma, the Rayleigh equation for fractional crystallization (Eq. 2) can be recast in terms of mineral compositions as:

$$
\mathrm{C}_{\text {mineral }} / \mathrm{C}_{\text {mineral }}^{0}=\mathrm{F}^{(\mathrm{D}-1)}
$$

where $C_{\text {mineral }}$ is the concentration of a trace element in a mineral of interest, $C^{0}{ }_{\text {mineral }}$ is the concentration of the trace element in that mineral at the beginning of crystallization, $F$ is the fraction of melt remaining, and $D$ is the bulk partition coefficient (Barnes et al. 2017, ESM 3).

For three samples of Russian Peak quartz diorite, values of bulk distribution coefficients were determined by trial and error to achieve the best fit between the calculated fractionation trends and amphibole compositions, as seen in Fig. 20, where the chosen $D$ values are given in the insets (note that two amphibole outliers at $\mathrm{Sr}=49$ and $52 \mathrm{ppm}$ and three other outliers at $\mathrm{Rb}=0.5$, 1.1 , and $1.3 \mathrm{ppm}$ were ignored in this exercise). The ranges in concentrations of the selected trace elements in amphibole are consistent with $40-50 \%$ fractional crystallization (i.e., $F=0.6-0.5$ ). A puzzling feature of Fig. 18 is the wide overlap in the compositions of amphibole cores and rims, which may result from combining analyses from three separate rock samples; for samples taken individually, there is a tendency for trace-element concentrations to be lower in rims than cores. Another problem lies in the difficulty in distinguishing cores and rims of three-dimensional grains in two-dimensional thin sections, especially in Russian Peak amphiboles that do not exhibit the pronounced core and rim color differences as those found in English Peak amphiboles.

For three samples of Russian Peak granodiorite, values of bulk distribution coefficients were again determined by trial and error to achieve the best fit between the calculated fractionation trends and amphibole compositions (Fig. 21), and as in quartz diorite, there is considerable overlap in amphibole core and rim compositions. Modelling for $\mathrm{Sr}, \mathrm{Ba}$, and $\mathrm{Zr}$ yields a high degree of fractional crystallization, viz. 80-90\% $(F=0.2-0.1)$. However, at $\mathrm{Sr}$ concentrations below $20 \mathrm{ppm}$ (as noted previously in Fig. 13), concentrations of Sc, Y, and Rb increase with a further decrease in $\mathrm{Sr}$. To achieve a match between the calculated fractionation trends and amphibole compositions requires a significant decrease in bulk distribution coefficients during crystallization: for Sc, a decrease from 1.8 to 0.5 , for $\mathrm{Y}, 2.4$ to 0.3 , and for Rb, 3.0 to 0.6 . Such large changes in bulk $D$ are contrary to the requirement in equation 5 that bulk $D$ remains relatively constant during crystallization, thus invalidating the modelling results for $\mathrm{Sc}, \mathrm{Y}$, and $\mathrm{Rb}$.

The question remains as to the cause of increases in $\mathrm{Sc}, \mathrm{Y}$, and $\mathrm{Rb}$ in amphibole at $\mathrm{Sr}$ concentrations below 20 ppm; such changes are also present in amphibole in the English Peak Chimney Rock Pluton (Fig. 13). Alkali feldspar is an abundant (10-30 modal \%) and late-crystallizing phase in granodiorite, and because the mineral-melt distribution coefficients for Sc and $\mathrm{Y}$ in alkali feldspar are $<1.0$ and those in amphibole are $>>1.0, \mathrm{Sc}$ and $\mathrm{Y}$ will be partitioned into amphibole during late stages of crystallization. The behavior of $\mathrm{Rb}$ remains enigmatic, because the mineral-melt distribution coefficients for $\mathrm{Rb}$ are $<1.0$ in both amphibole and alkali feldspar.

\section{Discussion}

The Russian Peak Plutonic Complex is similar in many petrological, mineralogical, and geochemical characteristics to other Late Jurassic igneous complexes of the Wooley Creek suite in the Klamath Mountains Province, most notably to the late-stage plutons in the neighboring English Peak Complex. The major difference between the two is that the English Peak late-stage plutons developed in an episodically recharged magma chamber in the upper middle crust, followed by final emplacement and differentiation in the upper crust (Barnes et al. 2016), whereas most features of Russian Peak quartz diorite and granodiorite reflect their emplacement and differentiation in the upper crust.

This difference in emplacement levels is most clearly recorded by differences in amphibole compositions. In English Peak late-stage plutons, amphibole commonly displays brown Ti-rich cores that initially crystallized at 
mid-crustal levels and were subsequently transported to upper levels, where they were joined by crystallization of green Ti-poor rims (Barnes et al. 2017). In contrast, amphibole in Russian Peak quartz diorite and granodiorite exhibits little compositional zoning and crystallized at an upper-crustal level (Cotkin and Medaris 1993). A further distinction between the two igneous complexes, again involving amphibole composition, is provided by a comparison of $\mathrm{Fe}-\mathrm{Mg}$ exchange coefficients for amphibole and rock (melt), which is defined as:

$$
\mathrm{K}_{\mathrm{D}}=(\mathrm{Fe} / \mathrm{Mg})_{\mathrm{Amp}} /(\mathrm{Fe} / \mathrm{Mg})_{\text {rock }}
$$

An average value for this $K_{D}$ in granitic systems is $0.28 \pm 0.11$ (Putirka 2016). The $K_{D}$ values in Russian Peak quartz diorite and granodiorite are $0.40 \pm 0.02$ and $0.33 \pm 0.05$, respectively, which are within error of the average value in granitic systems. In contrast, the $K_{D}$ values in English Peak late-stage plutons range from 0.76 to 0.92 . These significantly higher $K_{D}$ values at English Peak reflect the presence of brown, Ti- and Mg-rich amphibole that crystallized at mid-crustal levels, followed by transport and addition to the late-stage magma chambers in the upper crust.

In Russian Peak quartz diorite and granodiorite, variations in major- and trace-element compositions of whole-rocks and amphibole are successfully modelled by a process of fractional crystallization, modified to some extent in quartz diorite by the resorption of clinopyroxene. An interesting result of the modelling exercise is that the calculated degree of fractional crystallization is lower for whole-rocks compared to that for amphibole. For quartz diorite, whole-rock trace-element modelling (Fig. 19) yields $10 \%$ fractional crystallization $(F$ $=0.9)$, and amphibole modelling (Fig. 20), 40-50\% fractional crystallization $(F=0.6-0.5)$. For granodiorite, whole-rock modelling (Fig. 18) yields $40 \%$ fractional crystallization $(F=$ 0.6 ), and amphibole modelling (Fig. 21), 80\% fractional crystallization $(F=0.2)$. Thus, granodiorite experienced a larger degree of fractional crystallization than did quartz diorite, and the degree of fractional crystallization was higher on the intrasample (hand-sample) scale (amphibole) compared to the intersample plutonic scale (whole-rocks). Such greater

Fig. 21 Trace-element compositions (ppm) of amphibole cores (filled circles) and rims (open circles) in Russian Peak granodiorite. Dotted curves show amphibole compositions calculated for Rayleigh fractionation from $F=1.0$ to 0.1 at 0.1 intervals, using the bulk distribution coefficients $(D)$ given in the insets. Note the range in $D$ values for $\mathrm{Rb}, \mathrm{Sc}$, and $\mathrm{Y}$. 
Fig. 22 Comparison of REE compositions of Russian Peak quartz diorite (QD; vertical stripes) and granodiorite (GD; stippled field) with that calculated for melts derived by $5 \%$ batch melting of an oceanic crustal source (gray field; McDonough and Sun 1995; Parlak et al. 2009) with amphibolite mineralogy (45\% amphibole, $45 \%$ plagioclase, and $10 \%$ garnet). Normalized by $\mathrm{C} 1$ chondrite of McDonough and Sun (1995).

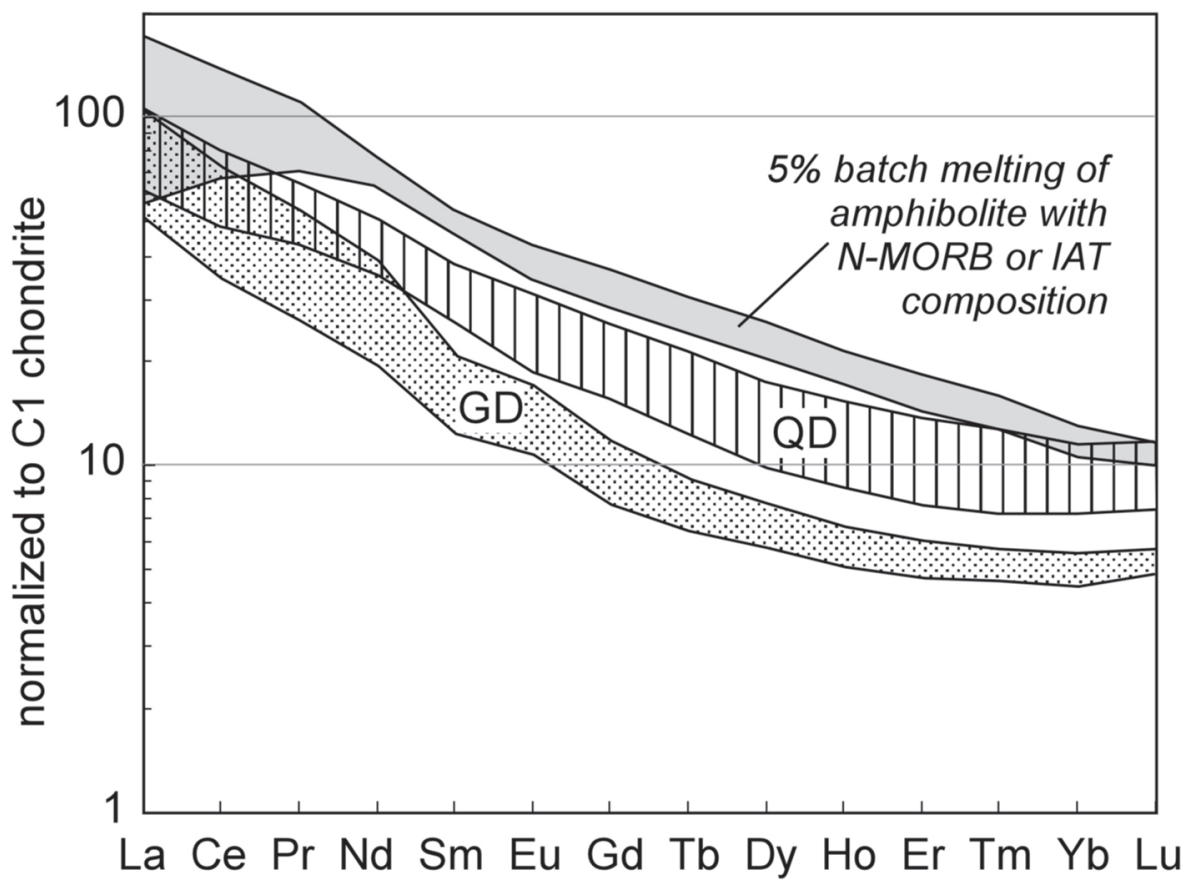

degrees of fractional crystallization would be expected to be recorded on the hand-sample scale, when minerals precipitating throughout the crystallization interval of an individual sample, such as amphibole in this instance, would have crystallized as $F$ declined from an initially high value to one ideally approaching zero at the end of crystallization.

In plots of certain major and trace elements in quartz diorite and granodiorite (Figs 8 and 9), discontinuities between the two demonstrate that they represent two separate batches of magma. Rare-earth element modelling for melting of protoliths with different combinations of minerals reveals that an amphibolite source is required to produce the REE patterns of quartz diorite and granodiorite; in this instance, $5 \%$ batch melting of garnet amphibolite (45\% amphibole $+45 \%$ plagioclase $+10 \%$ garnet $)$ with the composition of N-MORB (McDonough and Sun 1995) or island-arc tholeiite (IAT; Parlak et al. 2009) yields a REE pattern that is slightly concave downward with a $(\mathrm{La} / \mathrm{Lu})_{\mathrm{N}}$ ratio of $\sim 10$, which is similar to those for quartz diorite and granodiorite, although at a slightly higher magnitude (Fig. 22). The absence of a pronounced $\mathrm{Eu}$ anomaly in the calculated REE pattern is consistent with partial melting of an amphibole- and plagioclasebearing source, because in amphibole the $D$ value for $\mathrm{Eu}_{\text {mineral }} / \mathrm{Eu}_{\text {melt }}$ is less than those for neighboring Sm and $\mathrm{Gd}$, and in plagioclase the $D$ value for $\mathrm{Eu}_{\text {mineral }} / \mathrm{Eu}_{\text {melt }}$ is greater than those for Sm and Gd, thereby offsetting each other in calculations of whole-rock Eu concentrations. For the same reason, a pronounced Eu anomaly fails to develop during crystallization of quartz diorite $\left(\mathrm{Eu} / \mathrm{Eu}^{*}\right.$ $=0.94 \pm 0.08)$ and granodiorite $\left(\mathrm{Eu} / \mathrm{Eu}^{*}=1.06 \pm 0.05\right)$ due to the coprecipitation of amphibole and plagioclase.
We interpret the REE compositions of quartz diorite and granodiorite to have been generated by partial melting of subducted oceanic crust and subsequently modified by fractional crystallization and crystal accumulation during emplacement of the resultant magmas in the upper crust.

\section{Summary}

In this investigation, the petrogenesis of the calc-alkaline granitic Russian Peak Plutonic Complex in the Klamath Mountains Province, northern California has been quantitatively evaluated by major- and trace-element modelling. Field relations, $\mathrm{P}-\mathrm{T}$ estimates, and discontinuities in major- and trace-element variation diagrams for the two principal plutons in the igneous complex indicate that quartz diorite and granodiorite crystallized from separate pulses of compositionally distinct magmas at an upper crustal level. The variations in $\mathrm{SiO}_{2}, \mathrm{Al}_{2} \mathrm{O}_{3}$, $\mathrm{MgO}$, and $\mathrm{CaO}$ in quartz diorite could have resulted from crystallization of $45 \%$ plagioclase, $69 \%$ amphibole, and $-14 \%$ (resorption) clinopyroxene and in granodiorite, from crystallization of $60 \%$ plagioclase, $26 \%$ amphibole, and $14 \%$ biotite. Trace-element variations record different degrees of fractional crystallization on the intersample and intrasample scales, i.e. for the quartz diorite and granodiorite suites $v s$. their individual samples. For quartz diorite, values of $F$ are 0.9 for the suite and 0.5-0.6 for individual samples, and for granodiorite, values of $F$ are 0.6 for the suite and 0.2 for individual samples. Initial quartz diorite and granodiorite magmas were likely generated by partial melting of amphibolitic oceanic crust, followed by emplacement of the magmas 
at an upper crustal level, where they underwent different degrees of fractional crystallization.

Acknowledgements. This investigation was supported by the Institute of Geology of the Czech Academy of Sciences through Grant RVO37985831 to Svojtka and Ackerman. We thank Brian Hess for preparing high-quality polished thin sections, John Fournelle for his direction in electron-probe microanalysis, Allen Schaen for his comments on an early version of the manuscript, Calvin Barnes and Carlos Villaseca, who provided thorough and constructive reviews that improved the manuscript, and Vojtěch Janoušek for his consummate editorial handling.

Electronic supplementary material. Tables with majorand trace-element compositions of the studied whole-rock samples and amphiboles are available at the Journal web site (http://dx.doi.org/10.3190/jgeosci.285).

\section{References}

Allègre CJ, Minster JF (1978) Quantitative analysis of trace element behavior in magmatic processes. Earth Planet Sci Lett 38: 1-25

Allen CM, Barnes CG (2006) Ages and some cryptic sources of Mesozoic plutonic rocks in the Klamath Mountains, California and Oregon. In: SNOKE AW, BARNes CG (eds) Geological Studies in the Klamath Mountains Province, California and Oregon. Geological Society of America Special Papers 410: 223-245

ARMSTRONG JT (1988) Quantitative analysis of silicate and oxide materials: comparison of Monte Carlo, ZAF, an $\varphi(\rho z)$ procedures. In: NewBury DE (ed) Microbeam Analysis. Proceedings of the $23^{\text {rd }}$ Annual Conference of the Microbeam Analysis Society. San Francisco Press, San Francisco, pp 239-246

BARKER DS (1983) Igneous Rocks. Prentice Hall, Englewood Cliffs NJ, pp 1-417

Barnes CG, Allen CM, Hoover JD, Brigham RH (1990) Magmatic components of a tilted plutonic system, Klamath Mountains, California. In: Anderson JL (ed) The Nature and Origin of Cordilleran Magmatism. Geological Society of America Memoirs 174: 331-346

Barnes CG, Petersen SW, Kistler RW, Prestvik T, Sundvoll B (1992) Tectonic implications of isotopic variation among Jurassic and Early Cretaceous plutons, Klamath Mountains. Geol Soc Am Bull 104: 117-126

Barnes CG, Johnson K, Barnes MA, Prestvik T, KisTLER RW, Sundvoll B (1995) The Grayback Pluton: magmatism in a Jurassic back-arc environment, Klamath Mountains, Oregon. J Petrol 36: 397-415

Barnes CG, Snoke AW, Harper GD, Frost CD, McFadden RR, Bushey JC, Barnes MAW (2006) Arc plutonism following regional thrusting: petrology and geochemistry of syn- and post-Nevadan plutons in the Siskiyou Mountains, Klamath Mountains Province, California. Snoke AW, Barnes CG (eds) Geological Studies in the Klamath Mountains Province, California and Oregon. Geological Society of America Special Papers 410: 357-375

Barnes CG, Ernst WG, Berry R, Tsujimori T (2016) Petrology and geochemistry of an upper crustal pluton: a view into crustal-scale magmatism during arc to retro-arc transition. J Petrol 57: 1361-1388

Barnes CG, Berry R, Barnes MA, Ernst WG (2017) Trace element zoning in hornblende: tracking and modelling the crystallization of a calc-alkaline pluton. Amer Miner 102: 2390-2402

Coint N, Barnes CG, Yoshinobu AS, Chamberlain KR, BARNES MA (2013) Batch-wise assembly and zoning of a tilted calc-alkaline batholith: field relations, timing, and compositional variation. Geosphere 9: 1729-1746

Cotkin SJ, Medaris LG JR (1993) Evaluation of the crystallization conditions for the calc-alkaline Russian Peak intrusive complex, Klamath Mountains, Northern California. J Petrol 34: 543-571

Cox KG, Bell JD, Pankhurst RJ (1979) Interpretation of Igneous Rocks. George Allen \& Unwin, London, pp $1-445$

Davis GA, Holdaway MJ, Lipman PW, Romey WD (1965) Structure, metamorphism, and plutonism in the southcentral Klamath Mountains, California. Geol Soc Am Bull 76: 933-966

Donato MM, Barnes CG, Tomlinson SL (1996) The enigmatic Applegate Group of southwestern Oregon: age, correlation and tectonic affinity. Oregon Geol 58: 79-91

Ernst WG, Gottlieb ES, Barnes CG, Hourigan JK (2016) Zircon U-Pb ages and petrologic evolution of the English Peak granitic pluton: Jurassic crustal growth in northwestern California. Geosphere 12: 1422-1436

Frost BR, Barnes CG, Collins WJ, Arculus RJ, Ellis DJ, Frost CD (2001) A geochemical classification for granitic rocks. J Petrol 42: 2033-2048

GoOdGE JW (1989) Polyphase metamorphic evolution of a Late Triassic subduction complex, Klamath Mountains, northern California. Amer J Sci 289: 874-943

Gribble RF, Barnes CG, Donato MM, HoOver JD, KISTLER RW (1990) Geochemistry and intrusive history of the Ashland Pluton, Klamath Mountains, California and Oregon. J Petrol 31: 883-923

Hacker BR, Donato MM, Barnes CG, McWilliams MO, ERNST WG (1995) Timescales of orogeny: Jurassic construction of the Klamath Mountains. Tectonics 14: $677-703$

HaRPer GD, Wright JE (1984) Middle to Late Jurassic tectonic evolution of the Klamath Mountains, California-Oregon. Tectonics 3: 759-772 
IRWIN WP (1960) Geologic reconnaissance of the northern Coast Ranges and Klamath Mountains, California, with a summary of the mineral resources. California Division Mines Bull 179: pp 1-80

IRWIN WP (1981) Tectonic accretion of the Klamath Mountains. In: ERNST WG (ed) The Geotectonic Development of California. Prentice-Hall, Englewood Cliffs, New Jersey, pp 29-49

Jochum KP, Weis U, Stoll B, KuZmin D, Yang Q, RaczeK I, Jacob DE, Stracke A, Birbaum K, Frick DA, GünTHER D, ENZWEILER J (2011) Determination of reference values for NIST SRM 610-617 glasses following ISO guidelines. Geostand Geoanal Res 35: 397-429

Leake BE, Wooley AR, Arps CES, Birch WD, Gilbert MC, Grice JD, Hawthorne FC, Kato A, Kisch HJ, KrivovicheV VG, Linthout K, LAIrd J, Mandarino J, Maresch WV, Nickel EH, Rock NMS, Schumacher JC, Smith JC, Stephenson NCN, Whittaker EJW, YouzHI G (1997) Nomenclature of amphiboles: Report of the Subcommittee on Amphiboles of the International Mineralogical Association, Commission on New Minerals and Mineral Names. Canad Mineral 35: 219-246

McDonough WF, Sun S-S (1995) The composition of the Earth. Chem Geol 120: 223-253

Mooring CE (1978) Petrogenesis of the Russian Peak Ultramafic Complex, Northern California. Unpublished M.Sci. Thesis, University of Wisconsin, Madison, pp $1-230$

Nandedkar RH, Hürlimann N, Ulmer P, Müntener O (2016) Amphibole-melt trace element partitioning of fractionating calc-alkaline magmas in the lower crust: an experimental study. Contrib Mineral Petrol 171: 71. DOI 10.1007/s00410-016-1278-0

Padilla AJ, Gualda GAR (2016) Crystal-melt elemental partitioning in silicic magmatic systems: an example from the Peach Spring Tuff high silica rhyolite, southwest USA. Chem Geol 440: 326-344
Parlak O, RizaoĞlu T, BaĞCi U, KaraoĞLan F, Höck $\mathrm{V}$ (2009) Tectonic significance of the geochemistry and petrology of ophiolites in southeast Anatolia, Turkey. Tectonophysics 473: 173-187

PEACOCK MA (1931) Classification of igneous rock series. J Geol 39: 54-67

PutIRKA K (2016) Amphibole thermometers and barometers for igneous systems and some implications for eruption mechanisms of felsic magmas at arc volcanoes. Amer Miner 101: 841-858

RoMEY WD (1962) Geology of Part of the Etna Quadrangle, Siskiyou County, California. Unpublished Ph.D. Thesis, University of California, Berkeley, pp 1-93

SCHUMACHER JC (1997) The estimation of the proportion of ferric iron in the electron-microprobe analysis of amphiboles. Canad Mineral 35: 238-246

Shand SJ (1943) The Eruptive Rocks. $2^{\text {nd }}$ ed., John Wiley, New York, pp 1-444

SHaw DM (2006) Trace Elements in Magmas. Cambridge, New York, pp 1-243

SNOKE AW, BARnes CG (2006) The development of tectonic concepts for the Klamath Mountains Province, California and Oregon. In: SNOKE AW, BARnes CG (eds) Geological Studies in the Klamath Mountains Province, California and Oregon. Geological Society of America Special Papers 410: 1-29

VAn Achterbergh E, Ryan CG, Jackson SE, Griffin WL (2001). Data reduction software for LA-ICP-MS. In: SYLVESTER P (ed) Laser-ablation-ICPMS in the Earth Sciences: Principles and Applications. Mineralogical Association of Canada, Short Courses 29, pp 239-243

Wright JE, FAHAN MR (1988) An expanded view of Jurassic orogenesis in the western United States Cordillera: Middle Jurassic (pre-Nevadan) regional metamorphism and thrust faulting within an active arc environment, Klamath Mountains, California. Geol Soc Am Bull 100: 859-876 